\title{
اللغة والصورة الفنية عند جورج لوكاتش
}

\author{
أ.م.د جواد كاظم سماري السا عدي / كلية 1آداب / جامعة الكوفة \\ الباهث مسنز مهدي مصطفى الفهاهيs/ كلية الآداب / جامعة الكوفة
}

هدفت هذه الدراسة إلى التعرف على اللغة والصورة الفنية عند لوكاتش , لأن الفن يمتلك لغة خاصة , وهي الأداة التي يمتلكها الفنان

الكاتب للتفاعل مع الآخرين , والكلمة في الثعر تكون موجودة من أجل صناعة منظومة تقدم لنـا عبر العلاقات المتكونـة منها صورة ـ فالعمل الفني الذي يحتوي عناصر معرفة الواقع ، هو انعكاس عارف وتمثل فني وجمالي لظواهره وأشخاصـه ، وعلاقاته ومخفياته وأحاسيسـه فيقوم

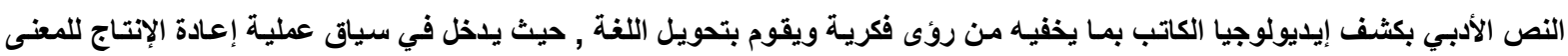

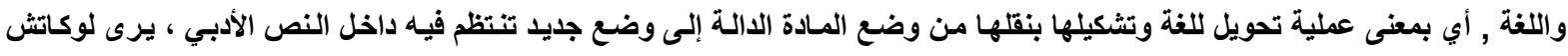
التسامي والسمو الثعري الذي سقط تحت هدير وسائل الإنتاج التي تملكها فردية الطبقة البرجوازية ، وتحول روح الإنسان و الفرد من التعبير

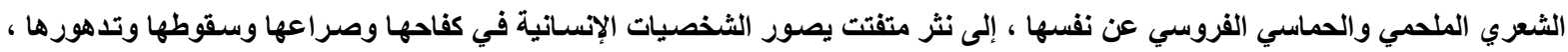

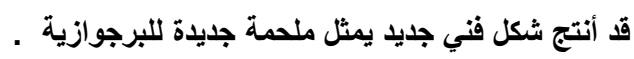

Language and The Image of Artistic for Georg Lukacs

Asst. Prof. Dr.JewadKadhimSemary Al-Sae'idy

Hassan Mehdy Mustafa Al-Khafajy

Kufa University - Faculty of Arts

Kufa University - Faculty of Arts

Abstract :

This study aims to identify the language and artistic image of Lukacs, because art has a special language, which is the tool that the artist has to interact with others, and the word in poetry is present in order to create a system that provides us with the relationships that make up a picture. The artwork contains elements of knowledge of reality, Is the reflection of Arif and represents the artistic and aesthetic of its phenomena and people, and its relations and hidden and sensations, the literary text reveals the ideology of the writer, which conceals the intellectual visions and transforms the language, where it enters the context of the process of reproduction of the meaning and language, A new situation in which the text is embedded in the literary text, Lokacs sublimation and poetic poetic that fell under the roar of means of production owned by the individual bourgeois class, The spirit of man and the individual transformed from epic and epic poetic expression of itself into a fragmented scattering depicting human figures in their struggle, conflict, fall, and degradation has produced a new artistic form that represents a new epic of the bourgeoisie.

: الإقدمهة

إن اللغة الفنية هي حقيقة اجتماعية واساسية ، وهي في الوقت نفسه معيار اجتماعي فقد كان أرسطو قد

اعطى كل شخصية طريقة كلام تتاسب طبيعتها ، اي بمعنى وضعها الاجتماعي كعنصر ممبز من بين عناصـر أخرى ، ولوكاتش الذي قد أوضـح أن تغيير العـالم والوجود الاجتمـاعي واشـكاله تعطي الأنموذج للانعكاس الصحيح ، حيث يضل النص في صراع مع الو اقع الاجتماعي الذي ينعكس عنهه ـ. وكانت نظرته الحى العالم قد أسست في التماثل بين النصوص الأدبية الكبرى وكذلك البنى الاجتماعيـة ، فالنص الادبي يثبه من حيث بنيته بآلية العالم ، حيث لايكون مجرد قول عن العالم ، بل يأخذ وضعا بالنسبة للعـالم فيدخل أنموذج كلي في تناسـب مع اصله . 
إن الصورة الفنية كصورة جمالية توقفنا عند محتو اها المباثر ، فيما يضمن لها التمثيل للوجود الاصيل للأشياء فهي لاتعد تمثيل مجرد بل انها خلق وابداع. ولوكاتش الذي يعدّ كل مضمون يفرض شكله الخاص، ومن ثم فان الثكل هو عنصر اجتماعي حقيقي في الاعمال الفنية. حيث انه بما كان المضمون الذي يتغير بتغير المر احل التأريخية وكذلك تغير رؤية الفنان الكاتب للعالم، فالثكل كذلك يتغير مع تغير المضمون بمعنى كل مضمون يفرض الثكل الخـاص بـه. لكن كيف يميز لوكاتش بين الانعكاس الطبيعي و الانعكاس الو اقعي في لغي

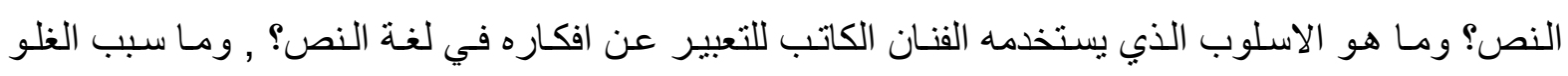
الثكلي في الفن البرجوازي, ومـا هو البعد الانطلوجي للصـورة الفنيـة عنده؟ ومـاهي العلاقـة بين الثكل الفني وبنية المجتمع، سوف نحاول الإجابة على هذه التساؤلات و غير ها ضمن رؤية تحليلية لنصوص لوكاتش في هذه الدراسة .

\section{أولا : اللغة والفهم الجمالي للنص في الأعمال الفنية}

لقد كانت رغبة الانسان في التعبير عن ما يدور في ذهنه من افكار وآراء ومعتقدات ، لا يمكن أن تتم إلا

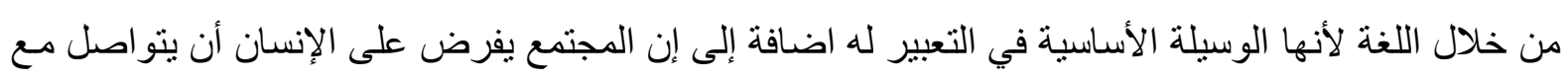

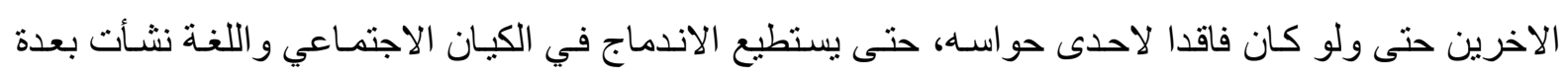

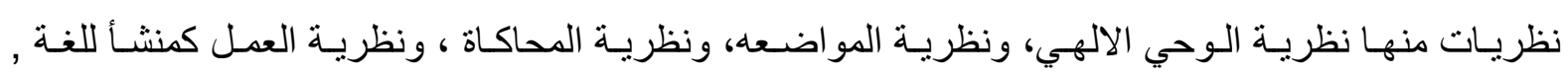
ونظريـة الاستعداد الفطري , ونظريسة التنفيس عن النفس ('). سـنكتفي هنـا للاشــارة فقط لهذه النظريـات دون

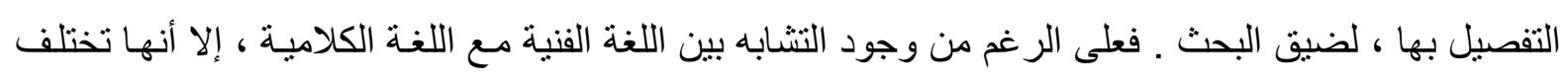

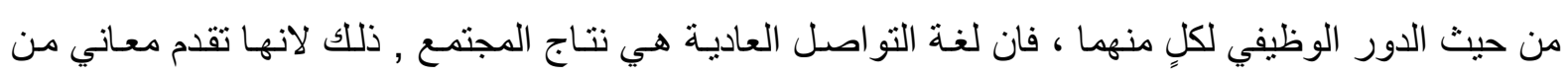

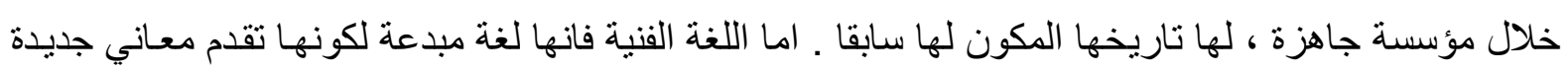
لقيامها على الفعل الابداعي للفنان الكاتب. لذا إن أهمية اللغة في اي عملية اتصـال فنية، كونها لا تأتي بصورة آلية , وليست نظام يمكن التكهن به مسبقا، و اللغة الفنية هي لا تسير وفق النظام الذي تعتمد عليه اللغنة العاديـة في توصيل المعلومات التي تخصها، فاللغة كما في الثعر تبدو تركيبية(؟).

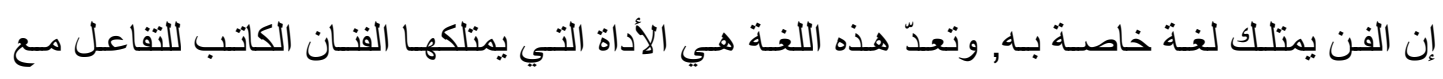
الآخرين, ففي العصور القديمة البدائية, عندما كان الفن نتاجاً لأناس يعيشون لكسب العيش, فكانت محاو لاتهم

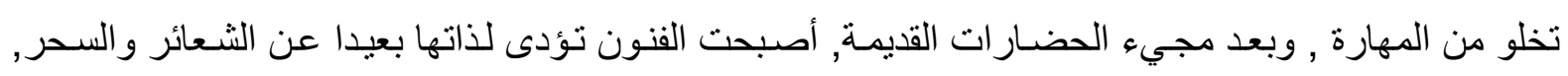
وبعد ذلك وصل الفن إلى ذروة منالية , بعد أن أتجه إلى الجوهر وتخلص من كل التفاصيل, ووصل إلى مرحلة

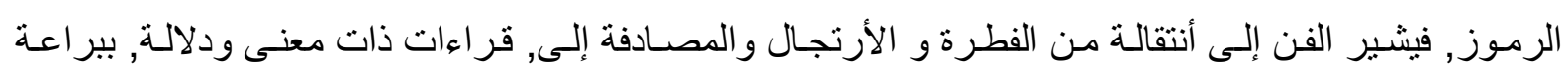
و إبداع فني رائع, فسارت عبارة عن نر اكمات تعبر في مضمونها وبأنثكالها عن إبداعات فنية وجمالية مذهلة(؟). إن الكلمة في الثعر هي تتواجد من أجل صناعة منظومة تقدم لنـا عبر العلاقات المتكونـة منها صورة,

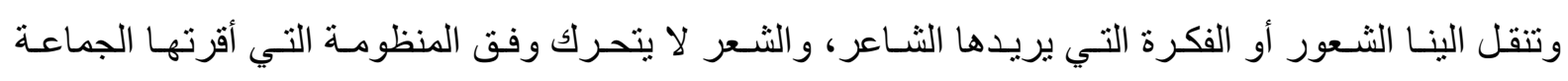
اللغوية, بل يقوم بكسر تلك المنظومـة, المدونـة, ويخرج بالكلمـة من معناهـا الوحيد الذي ينطق بها إلى معاني 
جديدة , حيث أن (رمان جاكوبسون(*) - Roman Jakobs) عدّ الثعر, هو أعنف منظم مقترف بحق الكلام العادي ـ يعني أنه إجتر اء على اللغة العادية, و إخر اج الالفاظ من مسار ها المعتاد في التعامل اليومي الى مسـار

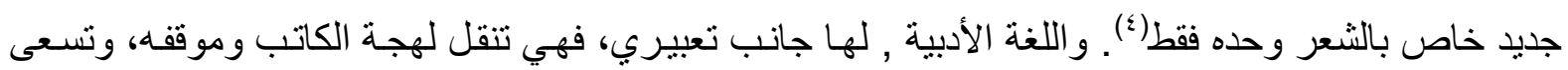
على نحو التأثير وبشكل فاعل في المتلقي وتتحو به الى التغير، فهي لا تكون قاصرة على البعد الدلالي لها فقط, انما أيضا يكون لها تعبير وايحاء، واللغة في الادب لا تمنلك استقلالية كما في الثعر , الذي يعتمد على التر اكيب

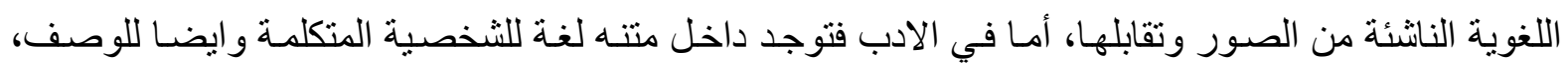
و هنالك لغة تقريرية في الأدب توجد شخصيات تم رسمها عبر اللغة، والشخصية في الرواية مثلاً انما تتألف فقط من الجمل و التي تصفها أو التي وضعها المؤلف على لسانها، و لا يوجد لتلك الثخصبة مـاض أو مستقبل، و لا حياة مستمرة لها احيانا، هذه الثخصية انما صنعت عبر كلمات وهي لا وجود لها خـارج النص, بالإضـافة الى ذلك توجد لدينا صورة العصر و الفترة الزمنية التي تتحكم في لغة العمل الفني، فيستخدم الكاتب اللغة التي تسود في مجتمعه لايصال أفكاره ومشاعره إلى الاخرين(ن)

و العمل الادبي في طبيعـة الحـال يتكـون من عدة لغـات فضـلا عن أنـه لغـة العصـر ، فـإن كثير مـن

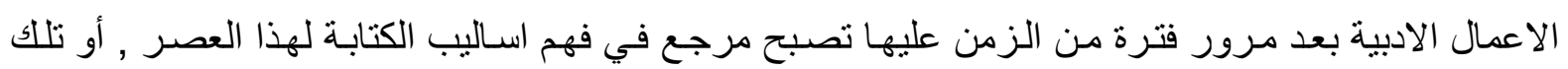
الحقبة ، واللغة في الادب تعبر عن الزمن ومروره, وتكوين الاحداث وتفاعل الثخصيات و النوازع الداخليه لهم

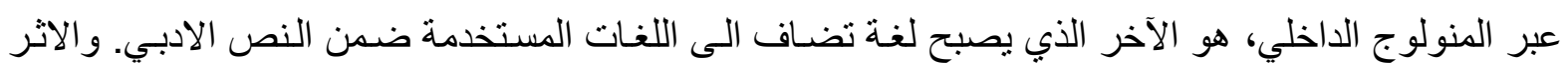

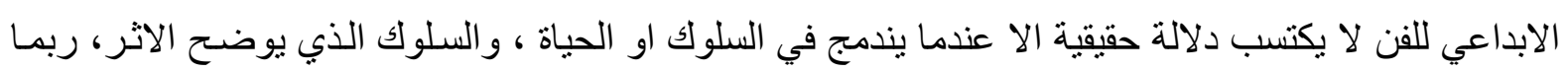
لايكون سلوك الفنان الكاتب ذاته , إنما هو سلوك الفئة الاجنماعية التي ينتمي لها الفنان الكاتب، فالفهم الجمالي الذي ير اه لوكاتش هو تحليل الابنية الداخلية للعمل الفني كمرحلة أولى، وتكون مرحلة التفسير لتحليل البيانات ودمج مرحلة الفهم فيها وتعبير هـا من خلال مرحلة ثانية ، لان الفهم هو كثف عن عن البنية الدالة المحايدة في

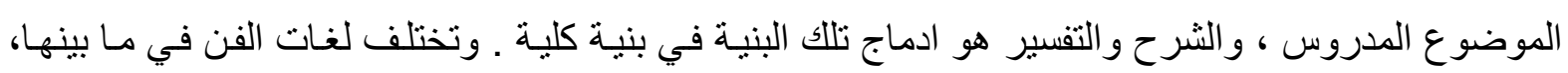
لكن الغرض التعبيري يكون هو غرضه الأساس فمن خلاله يتكون المنظور الذي يقدمه الفنـان ليوضح رؤيته لذلك العـالم ، فـن خـلال العمل الفنـي الحامـل للرؤيـة، يحصـل المتلقي على تلك الرسـالة عن طريق تعبيرهـا و وايحاءها الذي من خلاله يمكن للإنسان استعادة الاحساس الذي فقد منه, إتجاه الموجودات والأشياء والآخر (ج) . ويقول شكلوفيسكي: ((يوجد الفن كي يستطيع المرء أن يستعيد الاحسـاس بالحياة ، ويوجد ليجعل المر هـئسر بالأثياء، حتى يجعل الحجر حجريا, إن هدف الفن هو نقل الاحساس بالأثياء كما هي محسوسـة وليس كمـا هي معروفة))(Y). إذن الفن يكثف عن جوهر الاشياء ويضعها أمام أنظارنا, ويجعلنا نخلع الزيف عنها ويؤثر فينا

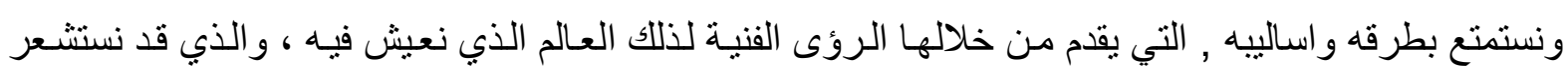
بأنتا نر اه لأول مره مع أننا نعيش بداخله وفي قلبة فكل هذا لا يأتي إلا عبر الفن , من خلال تنو عاتهـ المختلفة التي لكل منها لغة خاصة , إن لوكاتش يعدّ تحليل العمل الفني يجب أن يندرج داخل بيانات أكثر شمولية ويتم

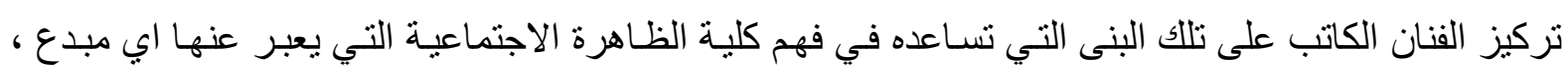


لأن المبدع هو لايعبر عن نفسه إنما يتكلم عن جماعة ، فلابد أن يكون التفكير في تلك البنية التي تتيح لنـا كليـة

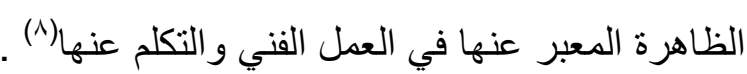

لقد أشـار ماركس في كتابه رأس المسال، المجلد الاول، في تعريفه التقليدي ليدناميات العمل ، في أن العمل في مقامه الأول هو عملية يشترك فيها كل من الانسـان و الطبيعـة ، وفيها يبدأ الإنسـان من تلقاء نفسـه ،

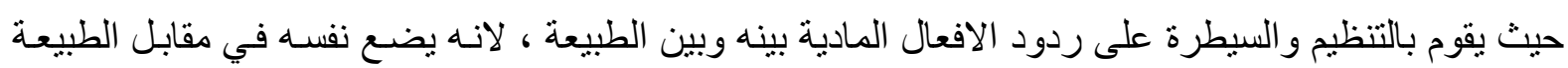

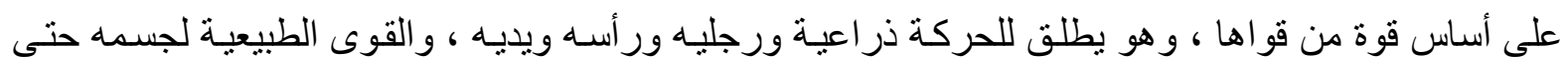
يمتلك منتجات الطبيعة بشكل يتفق مع احتياجاته، لذلك فهو عندما يشتنغل ويعمل على العالم الخـارجي وينيره ، إنمـا هو يغير وفي الوقت نفسه طبيعته فيطور قواه ، وير غمها على أن تسلك وفق تأثيره ، إن هذه العملية الخلاقة التي ير اها ماركس، لانها تبدل الطبيعـة من بدايـة أول صناعة لاداة أو اختر اع بدائي إلى اثتد منتجـات

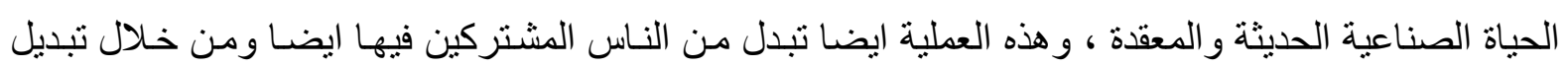

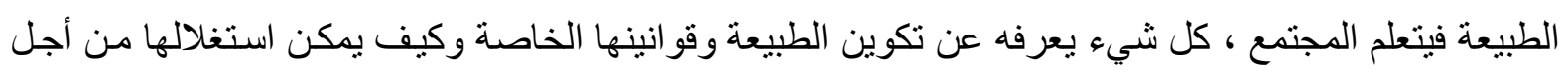
المزيد من التبديل في الطبيعة , التي هي عند ماركس شيء موجود مختلف عن الناس وبقو انينها وبأفعال العمليـة الاجتماعية يولد البثر الكلمات والاصو ات الموسيقية والعبارات والصور ر , وتكوين الصور و الكلمـات بكيفياتها

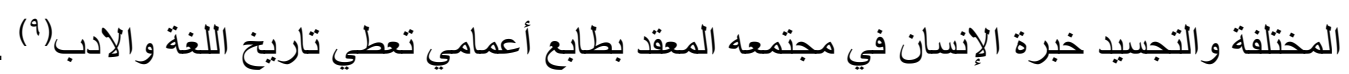

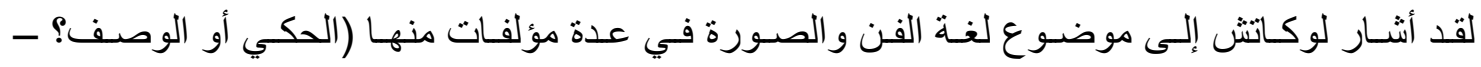
(The Theory of The Nvel - Erzahlen odr beschreiben ? و(الكاتب و الناقد ؛ الفن والحقيقة الموضوعية - Writer and Critic, and other essays) و (نحو أنطولوجيا للوجود الاجتمـاعي -zur Ontologie des gesellschaftlichen Seins) و (الروح والأشكال - Soul and form) و (در اسـات في الواقعية - Essays on realism) و (أدب ، الفلسفة ، ماركسية - Mitterature , Philosophie ,Marxisme), لقد انطلق لوكاتش من تللك العلاقة بين الأفكار الجمالية وبين المجتمع الذي أوجدها, و المسلمة التي ينطلق منها أن لكل عمل فني , بغض النظر سواء كان قديم

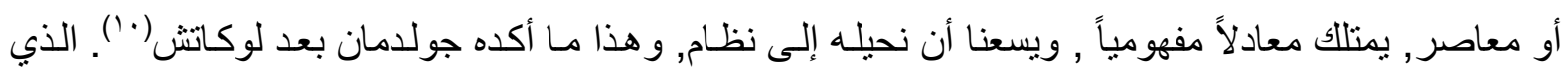
اشتغل على السوسيولوجيا الأدبية التي دشنها لوكانش من إنتاج عمل فردي خاص بـه ، و عيني وفن الصسورة ، الــي وجـد تحليلـه الماركسـي في نتاجـات المسؤرخين وبالخصـوص (كلينجنـدر - F.Klingender)، عـام

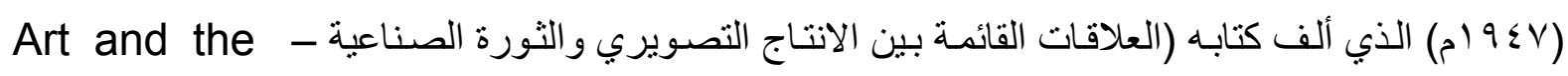
(Industrial Revolution ، حيث يـرى أن الاعمـال الفنيـة قد أسهـت بتلك الثورة التي بـأت منذ القرن الثامن عشر, أكثر مما كانت انعكاس لها، فالفنانون كانوا مسهمين في سيرورة تلك الثورة ، وايضـا أوضـح (فريدريك أنتال- F.Antal)، في كتابه التعايش القائم في القرن الخامس عشر , ضمن سياق واحد يبين اعمال فنية يوجد اختلاف شديد بينها على صعيد الثكل ، كصورة العذراء التي رسمها (ماز اتشبيوا - Masaccio)، حيث كان أنتال قد رأى في تلك الصورة, انعكاسا لتصور العالم على نحو مختلف لدى طبقات المجتمع المختلفة 
في العصر الذي ازدهرت فيه اوضاع الطبقات الوسطى, والطبقة البرجوازية العليا التجارية والمالية, التي كانت تعزز العقلانيـة في انمـاط التصـور, وتدخل عليها التفكير الحسابي الرياضـي، فعدّت هذه الصسورة تقدميـة أمسا الصورة التي رسمها (جنتيل دا فابريانو - G.da Fabriano)، حيث عدّت هذه اللوحة رجعية(') .

ثانيا: جدلية النص والهاقع في العمل الفني

إن لوكاتش حينما يصف بلزاك ، الذي يعتمد على التركيز الدرامي ، حتى يفجر طاقته الثـعرية والحيويـة في أعماله ، فإن هؤ لاء الكتاب الذين يكافحون في سبيل التغلب على التفاهـة والفراغ في الحياة النثريـة بطريقة بطولية ، من خـلال حدته الدراميـة والتركيز الأنموذجي في تحويل النتر المسكين في الحيـاة الى عـالم الثـعر الإنساني , المليء بالحركة والعمق واللون الاصيل , وقد زعم الطبيعيون في انهم تجاوزوا الرومانسية الذليلة بالوصف الادبي لتفاهات الحياة اليومية وما تطفح به من غباء وحزن تقيل ، مـع أن لوكاتش يرى أن الطبيعية

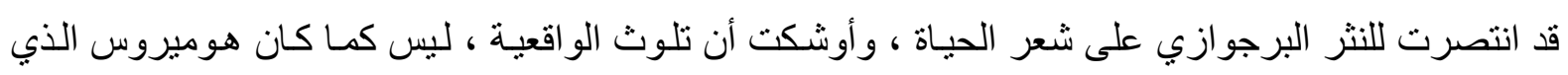

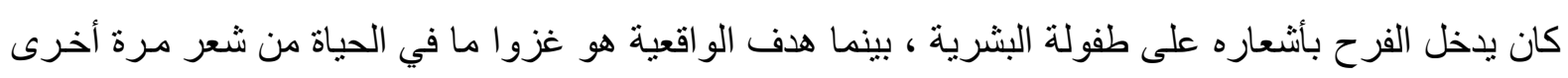

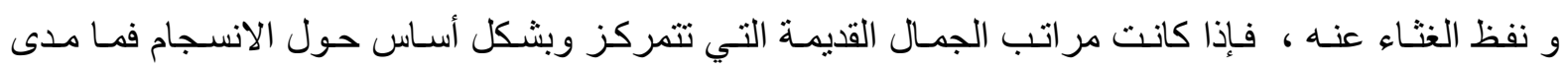

الاعتداد من قبل و اقعية لوكاتش لهذا المحور ؟ ؟ (r') .

يوضح لوكاتش كيف أن الكاتب الواقعي في المجتمع الر أسمالي الغربي والمتطور قد رفض وصفه من

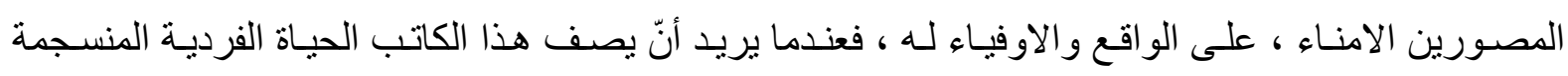
و الجميلة ، فليس أمامه إذا أراد أن يجسم ظروف عصره , الا أن يصور ما في الحياة من تمزف وعدم انسجام ،

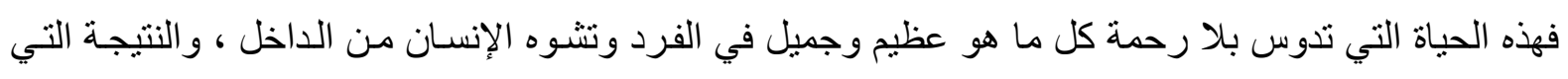

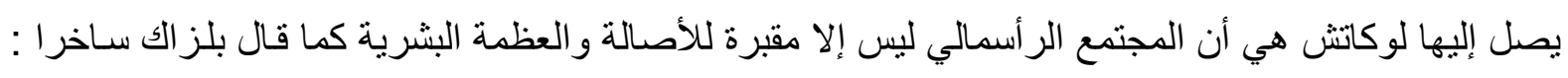

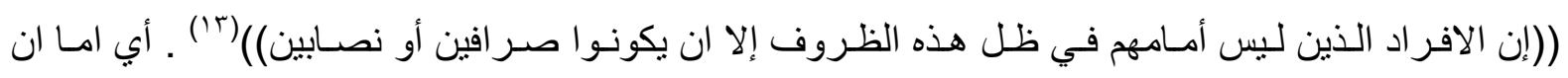
يكونـوا أغبيـاء ويقوم الآخرون باستغلالهم أو أنذالا يقومـون هم بهذا الدور الاستغلالي ، لذلك فـان الانسـجام

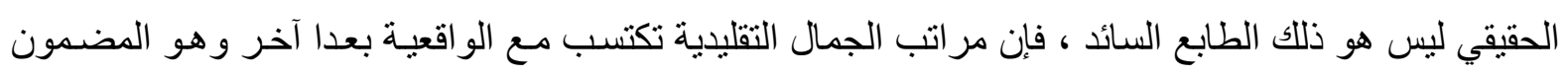
الاجتماعي ليحل محل الانسجام تصور آخر يقوم على أسـاس أن العمل الفني إنما هو كون صغير يمثل كون كبير (ع (').

ويطر ح لوكاتش في كتابه نظرية الرواية مسألة (الثنائية الموضوعية - Thematic duality) ، ذلك

التوتر بين مصير مرتبط بالارض ووعي يحاول أن يتجاوز هذا الوضع ، حيث تقود هذه المسألة إلى انقطاعات بنيوية في شكل الرواية ، وتجاهد (الكلية - Totality) ، من أجل استمر ارية تنهض للمقارنـة مـ وحدة كيان عضوي ، لكن الو اقع المغرب يتدخل في هذه الاستمر ارية ويقطعها ، و الى جانب الاستقرار العضوي المنسجم

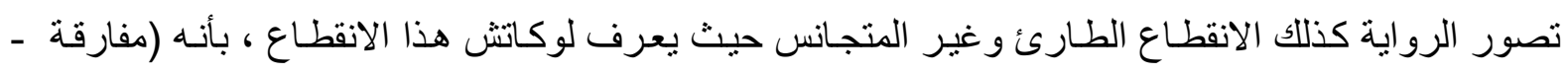

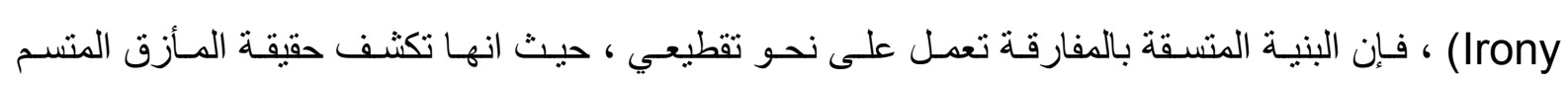

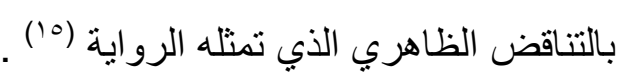


إن لوكاتش يعدّ المفارقة وسيلة يتتم مـن خلالهـا تجـاوز الكاتب ، ضـمن شكل العمل الاحتمـال المعلن لوضعه، فيقول لوكاتش : ((إن المفارقة في الرواية هي حريـة الثـاعر بالنسبة للإلهي ، فنحن نستطيع بواسطة

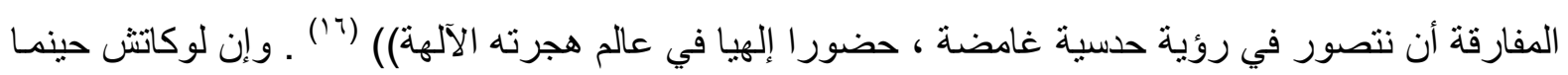
يصف مفهوم المفارقة بوصفه قوة ايجابية (للغياب - Absencc) ، فهنا يظهر تأثثر فريدريك شليغل ، وايضـا هيجل ، الذي يبين استخدام لوكاتش مفهوم المفارقة كمقولة بنيوية ، فإذا عدّ لوكاتش المفارقة كمبدأ محدد ومنظم لنكل الروايـة ، فبذلك قد حرر نفسـه من الافكار المسبقة في تصوير الروايـة محاكاة للواقع ، فالمفارقـة هي تضعيف على نحو مضطرد , زعم المحاكاة للواقع وتستبدل به وعي مفسر للمسـافة التي تفصل التجربـة الفعلية

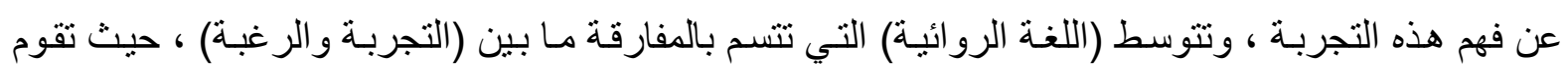

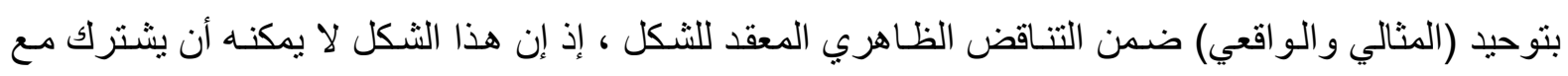
الثكل العضوي المنسجم للطبيعة ، فإنه يؤسس على فعل و عي وليس على محاكاة موضوع طبيعي ، فـإن صلة

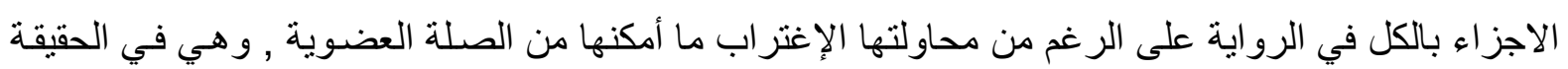
صلة (مفهوميه - Concept) ، فتكون (معلقة ابدا - Ever Suspended) ، اذ إنها ليست صلة عضدية حقيقية حيث نرى لوكاتش هنا يقترب وبشكل كبير في بيانات من هذا النوع للوصول إلى نقطة يمكن أن يبدأ منها (علم التأويل - Hermeneutic) ، ذلك العلم الحقيقي لتأويل الروايـة مـع أندُ في مقالـة أخرى من كتابـه

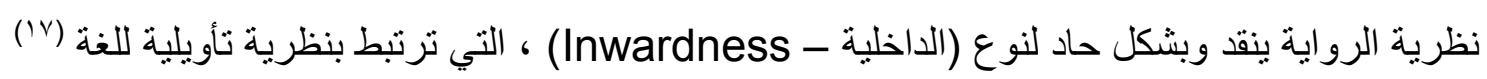

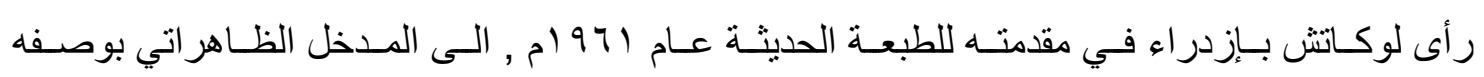
(إبستمولوجيا يمينيـة - Right wing epistemology) ، في أنهـا تمضـي في اتجـاه معساكس للاخـلاق اليسارية ، فقد كان هذا نقدا ضمني لكن لوكاتش عندما يقترب تنـاول التطورات المعاصرة في الرواية وفي لحظات يبدو أن الرواية نفسها قد اصبحت فيها واعية بقصدها الحقيقي ، فيحدث تحول كاثف في المحاجة وهو

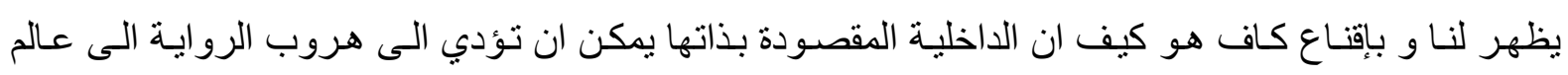
يوتوبي ، اي يوتوبيا لها من البداية ضمير سيء ومعرفة بهزيمتها ذاتها (^’'). لقد أخذ على واقعية لوكاتش أهمالها الجانب الثنكي لصياغة الأعمال الفنية للكتاب ، أي إنه لا يعطي عناية كافية للثكل في الاعمال الفنية ، فعندما يتحدث عن المضمون المصور الذي يمثل اللحظـات الواقعيـة, فلا توجد نوع من الواقعية تعبر عن نفسها , عندما تتكثف الانسانية في لحظات معينة من الصيخ الثكلية, حيث تتصل هذه القضية باللغة ، حيث يرى لوكاتش أن من أثند الاخطار أن ننظر الى الفن من زاويـة شكلية محضـة

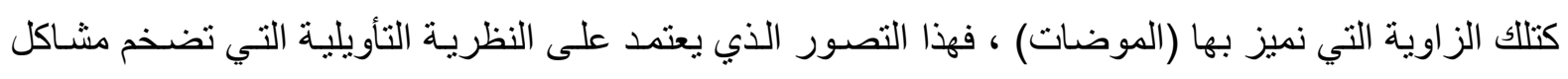
الصياغة و التجديد اللغوي حتى اصبحت تعد مشاكل مستقله بذاتها ، لكن التجديد اللغوي يسهم وبشكل جوهري يُهي

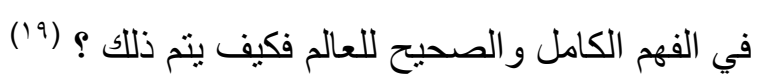

يرى لوكاتش اذا كان التجديد اللغوي سيندمج في اللغـة العالميـة ويفقد عندها طابعهـ التجريدي ، والا فيذهب هباء لذلك و على هذا فالمضمون هو أولا وقبل كل شيء مـا يجب أن يؤخذ في الاهيـة ، ولا يجب أن 
ننطلق من مشاكل تكنيكية، لكن يجب أن نسأل دائما عن المحتوى العظيم لكل عصر لان هذا المحتوى الذي ينتج ويكيف اشكالا محددة من التعبيرات اللغوية ، و هو الذي يبقى بعد ذلك مؤثرا في تطور الاجيال اللاحقة ، ونتيجة لذلك فإن مشكلة اللغة الفنية التي ير اها لوكاتش تواجه الواقعية النقدية هي دراسة لغة الثـاعر القديم , ذات أهمية

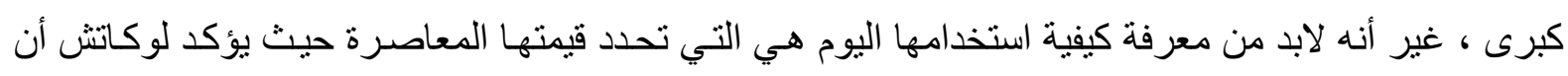
المهر , هو مدى ما يكتشف فيها من عناصر فنية يمكن ان تتحول لدى من يكونون قادرين عليها ويحسنون

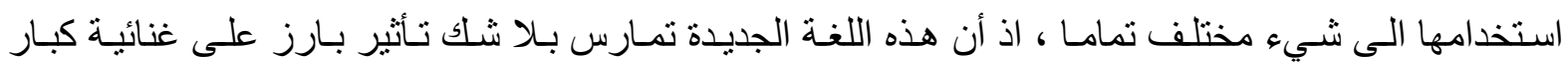

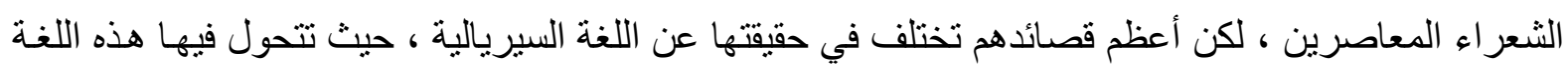
الى عنصر واحد من مركب معقد خصب يعبر عن شيء هام بالنسبة للثخصية المعاصرة (r.") إن لوكاتش يعدّ إفتقار الدلالـة الانسـانية والمحتوى الاجتمـاعي في الفن البرجوازي لن يودي الى الغلو

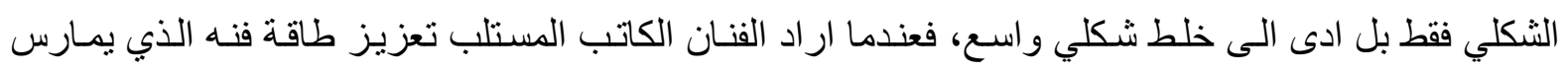
بطاقات فنون أخرى، حيث خلط في تلك الاعمـال الفنيـة بين منـاهج البناء والتكوين والادوات الفنيـة. ويعزوا لوكاتش سبب الغلو الثكلي الذي هو في ذاته خلط شكلي الى عجز الكاتب البرجوازي المستلب عن ادراك مابين الجماليات وايضا قضايا المجتمع والانسان من علاقة جدلية. كذلك فإن افتقار الدلالة الانسـانية والمضمون الاجتماعي قد أديا باللغة كأداة للادب في الضمور الثديد في وظيفتها وقصور طاقتها ففي الادب المغترب لم تعدّ اللغة، تربط الانسان بالإنسان، انما اصبحت اداة تؤكد الانعز ال، حيث إن التصـاق اللغـة في الاعمـال الفنية بالعرضي والمباشر وبذلك عجزت عن تجريد فكري فني وقصور عن الاعمام الجمالي (rان. بما أن لوكاتش يستند على ماديته الجدلية كذلك ويرفض عزل النص وأغلاقه على نفسـه ، فيركز على مبدأين اساسيين، المبدأ الاول: هو نوعيـة العلاقة الموجودة بين الفكر والواقع، و المبدأ الثناني: إن للفكر موقعـه الطبقي للمجتمع، وهذا ما يجعل النص في العمل الفني نص يحمل رؤيـة للعـالم، حيث ينوجـه النقد في تحليله، و الكثف عن هذه الرؤية إذن تصبح مهمة النقد هي البحث عن هذه العلاقة بين النص و الواقع الاجتمـاعي، ثم بعد ذلك يجري تحديد الموقع الفكري الذي تنهض منه هذه العلاقة. فإن لوكاتش يركز وبشكل اساس على الوعي الاجتماعي في النص الادبي، ويرفض ايضا أن يكون النص مجرد لغة، بل يرى أنه فيمـا هو كذللك يحمل رؤيـة

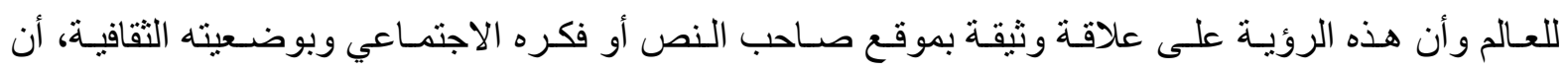

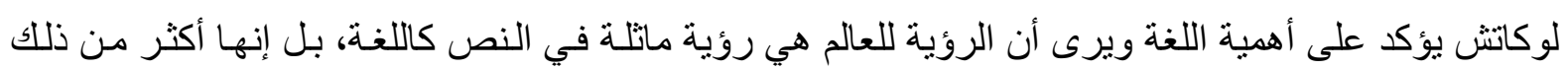

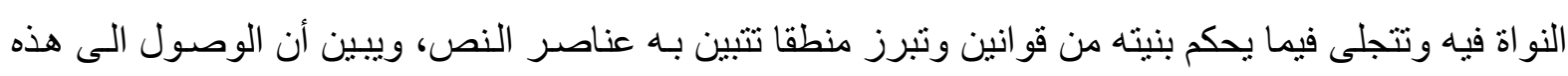
الرؤية لا يكون إلا بقر اعة لغـة النص، أي بمعنى تحليلها بحيث تتكثف لنا هيكلية النص فنطول هذه القو انين ونسنبين تحكمها به (rr)

فإن الجمالية التي يشير لها لوكاتش في النص الادبي تظهر في نظام التركيب اللغوي في النص الادبي، أي في بنية تركيب الجمل و المفردات، كمـا في بنيـة الزمـان و المكان التي تولد فضـاء النص وتخلق للفعل فيه مسافة ينمو فيها وارضا يتحقق عليها ، فينسج العلاقات على اكثر من محور تتقاطع وتلتقي وتتصـادم وتخلق 
غنى النص وتتعدد امكانيات الدلالة فيه ـ. اذ ان هذه الجمالية في نظـام البنيـة نفسها للنص الثـعري اي مـا يحكم التركيب فيها تكر ار يفجر المعاني ، ومن معاودة تجدد هذه المعاني وتنوع عليها ، ومن توازنات ومعادلات

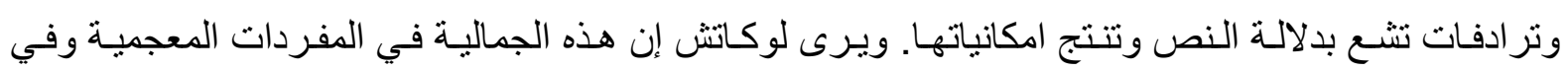
الحروف و الاصو ات، وفي ما يولده كل ذلك من رؤية ليست بمعزل عن الرؤية التي تحكم اتجاه أدبي في مرحلة

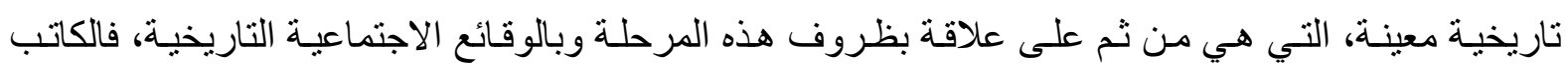

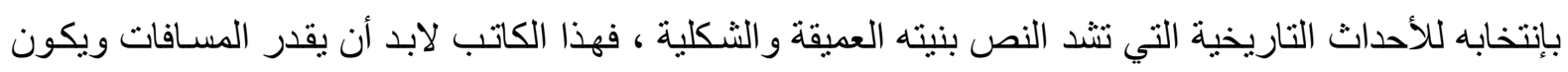

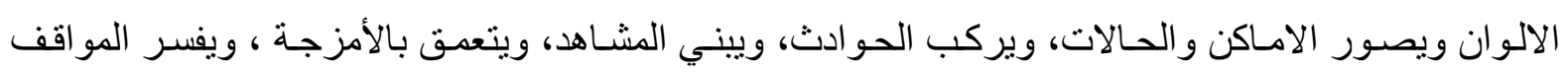
ويكوّن في قلب تمفصـلات المجتمع(rr). لذا لوكاتش يقول في الروايـة التاريخيـة: ((رو ايـة تاريخية حقيقية أي

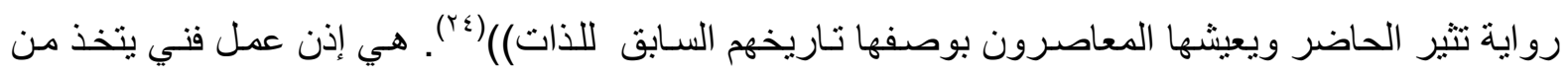

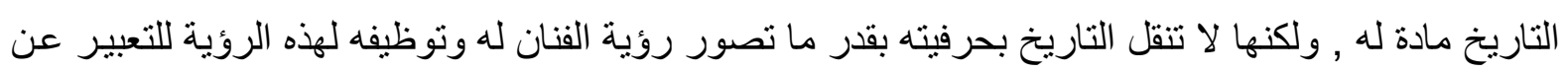
تجربة من تجاربه أو موقف من مجتمعه يتخذ من التاريخ ذريعة له (ro)

\section{ثالثا: الكمال وتربية الفرد جماليا}

يرى لوكاتش الرواية بوصفها جنس أدبي سردي في لغة نثرية ، الذي له خصائصسه ومكوناته التي تتغير

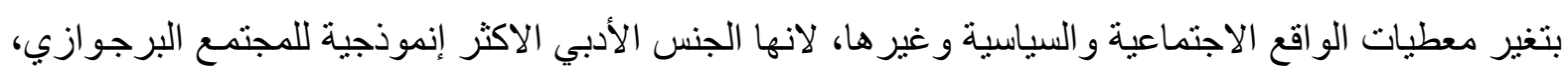

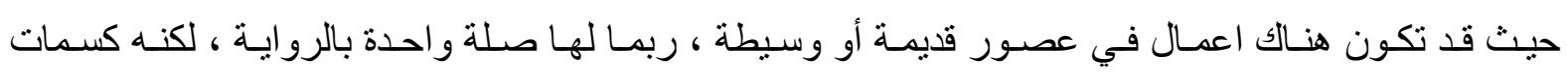
إنموذجية للرواية لاتظهر إلى حييز الوجود إلا بعد أن أصبحت الروايـة كثكل تعبيري للمجتمع البرجوازي،

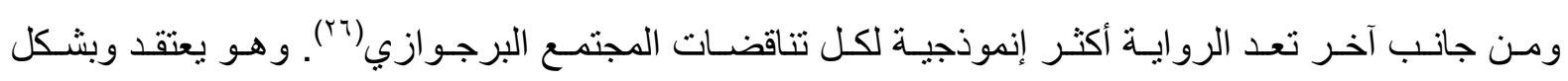
موضوعي لابد على الفنان الكاتب أن يغوص في دواخل الذات و التـاريخ والمجتمع من خـلال العودة من جديد إلى الماضي الفردي والجماعي ، ومن غير أن تظهر هذه العودة كقيمة سلبية في انبثاقها وتحولها إلى تأليف فني أدبي يحاكي التاريخ القريب او البعيد كمعطى فني إبداعي لا كتوجهه مقصود يوظف لغرض معين يستدعي

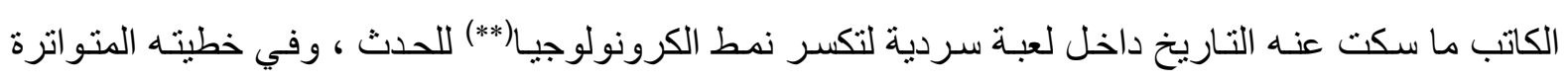
حتى تعطي السرد واللغـة تتامي يجعل الحاضر يذوب بالماضي ، حيث إن هذه العودة للتاريخ ير اهـا لوكاتش تتمظهر في قدرتها في نوع من القراءة للتاريخ مسقطا على الر اهن و الو اقع بوصف أن النص المستوحي للتاريخ

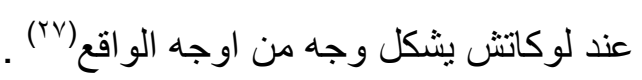

إن لوكاتش ينظر إلى عدم إكتمـال الاعمـال الفنيـة و الروايـة على وجـه الخصوص ، هو نـاتج لتجسيدها الواقع الانساني، وهموم هذا الو اقع، وبذلك سوف يظل التحول السردي بين مطرقة الرؤيـا وسنديانة التكوين ،

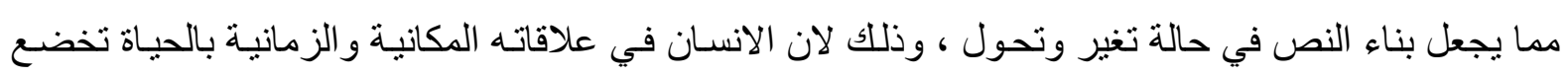
للتغيرت والتحو لات التي تستو عب تتاقضـات يعيشـها الانسـان في عالمسه الخـارجي والداخلي ـ فالتأليف و الكتابـة

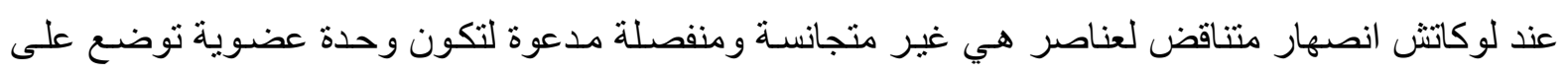


الدو ام موضـع تسـاؤل ـ فالاعمـال الفنيـة لا تكون خاضـعة لقوانين ، بسبب التحـولات والتغيرات التـي يعيثـها

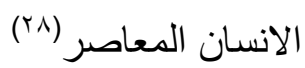

إن الابداع الفني بوصفه صورة الواقع, والمبدع لا ينقل الموضوع كما هو إنما يتدخل في الصياغة الفنية

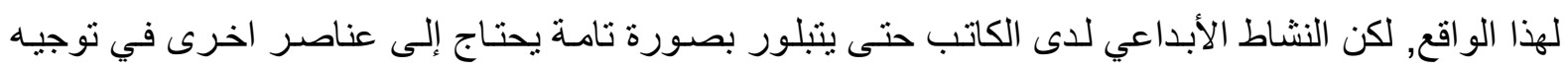
المتلقي وتربيته جمالياً في نقد أثكال الابداع الفني. فالتعرف على العناصر الجمالية في أي عمل فني يكون لهن

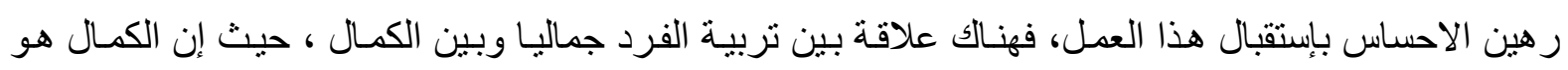
تعبير قديم إنبثق من كلمـة لاتينيـة (totus) التي معناهـا اعلى درجات التقدير وتقوم على الجهود الفنية للفنـان الكاتب وخصوصا في المر احل النهائية من ابداعه الفني، بعد أن تتماسك الاشياء وتتحد العناصر في اعلى درجة دئة من المعاني والاحاسيس، فيرى لوكانش إن هذا الانسـان المبدع لـه القدرة على تحويل المتلقي للعمل الفني الى لى درجة الكمال لكن لوكاتش يفرق بين تعبير الكمال في العالم، والكمال في العمل الفني. فالكمال في العالم هو كلي

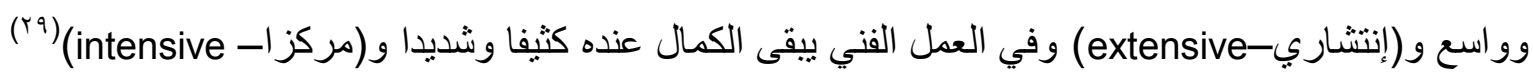
إن لوكاتش يوصفه للعمل الفني بالكمال المكثف والمركز ، لإعتقاده إن الاعمال الفنية تعكس لنـا الحياة بلغة فنية ، لكن في نسبية وحقيقة يظهر من خلالهمـا الغايـة في العمل الفني ، و التحديدات الادر اكيـة التي تقيم

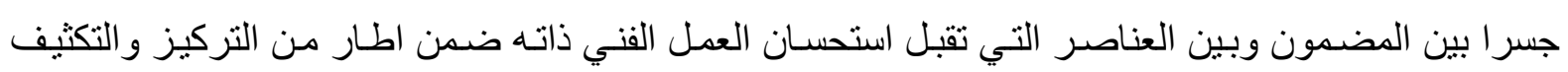
الثديدين ، فنظرته للكمال مرتبطة بالو اقعيـة اذن هناك علاقة بين الكمال والتربيـة الجماليـة للفرد كأنها علاقة فئة الثكل بالمضمون، فالاحساس يتم من خلال الفهم والادر الك والتذوق في صورة مكتملـة ، و الاحسـاس بهما يوجد في تضافر هما الذي يوصلنا الى الكمال حيث يصبح الكل في واحد، ما هذا الكل إلا هو جزيئآت متناثرة في كل

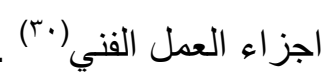

لوكاتش يعدّ الواقع الذي ينظر اليه الكاتب ويعيشـه بوصفه القضية المركزيـة في العمل الفني يقدم في بعض الاحيان بلغة ذات خاصية فنتازية، حيث أن تركيب أجزاء الواقع كما يثاهدها الكاتب قد تجعل من المكان

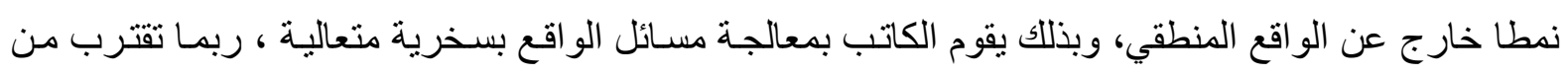
حكايـات (رحلات جوليفر) لـجوناثان سويفت الذي قام بتوظيف الحوار فيها بين التجربـة المدنية التي يمثلها مجتمع سويفت وبين تجربة مجتمعات صادفها في رحلته واطلع عليها من عمالقة أو أقزام أو احصنة ، لقد كانت هذه المسألة من أجل النقد لمجتمعه وبصورة غبر مباشرة تقوم على أساس إيجاد نوع من الغرائية الغير متوقعـة

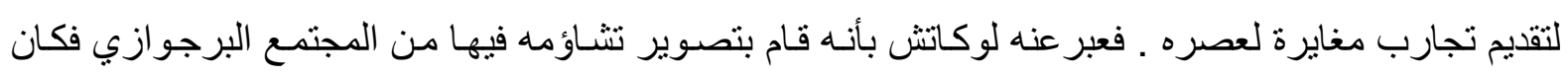

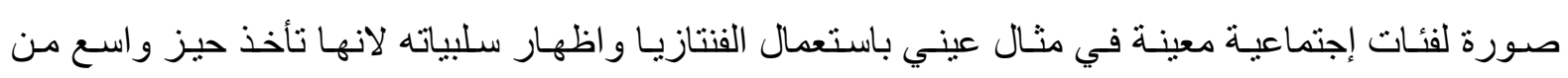

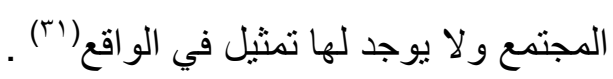

\section{رابعا : جمالية الصورة الفنية في النص}

إن الواقع الخـارجي بوصفه هو واقع معين ، أمـا الواقع في النص فهو تعبير عنسه ولكن الصـلة بين الكلمات و المرجع هي ليست مباثرة وتكون جدلية فيوجد واقعان الاول هو واقع الخطـاب نفسـه ، و ايضـا الثاني 
الو اقع الانساني الخارجي بكل ما يحتويه من انتاج وممارسـات وان يكن الواقع في النص جزءا منها ، فالنص الادبي هو مزيج من الواقع وانواع التخييل لذا فهو يولد تفاعلا بين المعطى و المتخيل و لان هذا التفاعل ينتج شيئًا اكثر من الفرق بين المتخيل و الو اقع، لذا يستحسن تجنب التعـارض القديم بينهمـا واستبدال هذه الثنائية

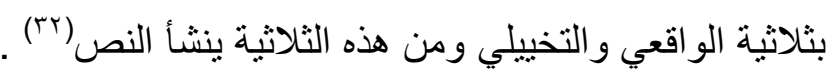
إن الصورة ليست مجرد تمثيل مباثر عيني ، بل إنها تعبر عن خلق وابداع ، والمحتوى الحي للصورة

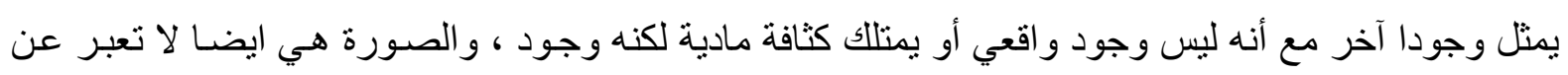
حقيقة لا تتنجها بوصفها معادل مفاهيمي لغوي للوجود ، فتعبر عن الوجود الاصيل سواء كان هذا الوجود مـادي

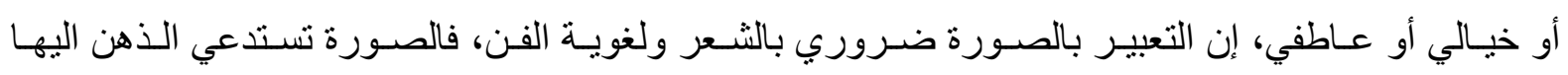

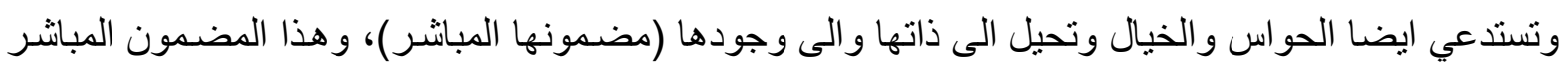

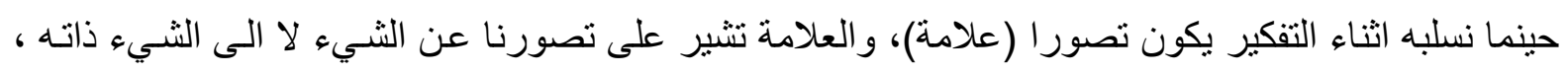
فالعلامة تشتغل وفق سياق التصورات والنظام الكلي، فالصورة الفوتغر افيـة تعبر عن علامـة نظرا الى سياقها التصنيعي وليس الى تمـام تمثيلها للثـيء، لكن صسورة الرجل في المساء هي ليست علامـة بالتأكيد والصـورة الايقونية بحد ذاتها بعيدا عن كونها تصنيعا سياقيا ، هي ليست علامة لانها لا تحيل بل تصور فر ادة الثـيء و لا

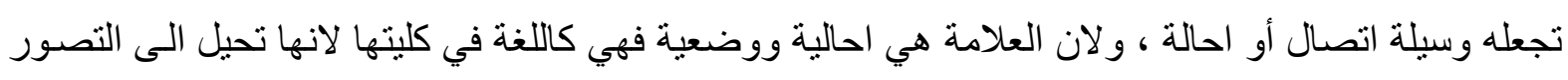
الكلي ، أما العلامة اللغوية في العمل الفني تصبح شبيه بالايقونـة لانها تقف عند الثـيء ذاته عند الكائن ذاته وله لارجة التماهي و التماهي يسبقه انفتاح ومجال التقاء لكي يحدث ، فتماهي العلامـة بالثـيء ضرب من التصوير

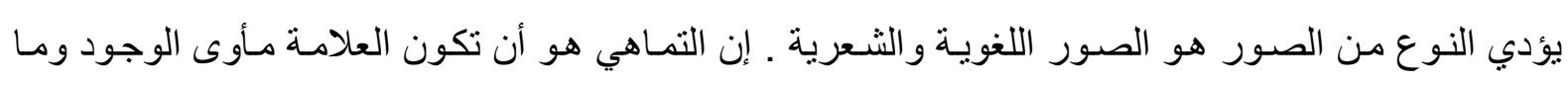

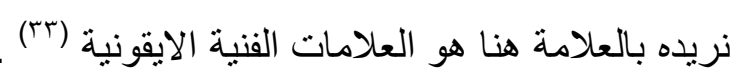

إن التواصل يكون حقيقي عندما يكون عـالم الصور هو مجال الالتقاء وهو الارض المحايدة ففي هذه الأرض يكون التو اصل بين مختلفين غير منتابهين، أي بين فرديات لا هيئات فليس العالم الخارجي هو وحدة

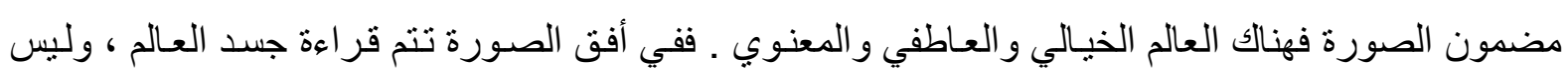
بوصفه علامات ودوال ، انما بوصفه إمتلاء انطولوجي مستقل ، لكن ما معنى كونه انطولوجي ؟ (عَ) . إن الالتقاء الانطولوجي حسب ما يرى لوكاتش بين الوعي و الثيء لا بد أن يكون في مجال مفتوح وحر

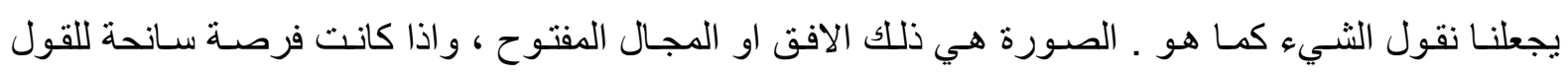
الثعري أكثر من أي قول آخر في هذا المجال ، ففي عالم الصورة التي تحيل الثيء الى ذاته و الى تفرده فيقول

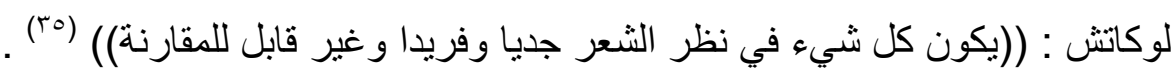

إن الالتقاء بالكائن دون هذا التحرر من التصورات يجعله يفزع ويخاف ، وثثم يهرب الى عدمـه الخـاص.

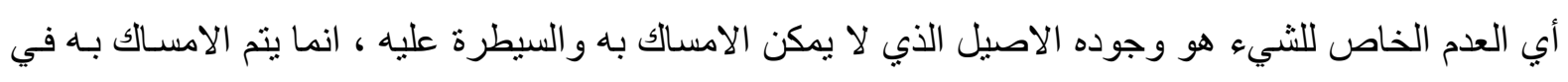
العالم التقي و التصنيع والتحويل هو الظلال للثيء لا الثيء ، ففي حديث الثُر وفي اللحظة التي ينكثف فيها العالم للثاعر والفيلسوف والفنان المبدع ، سوف تتعرض الرؤيـة للانبهار جذاب و انخطاف روحي عارم وهذا

\section{$-r \leq \varepsilon$}


الذي اصبح دارجا تسميته بالالهام وهو الخيال الذي تحرر في عالم الوجود الاصيل ، عـالم الصور بعد الصحو

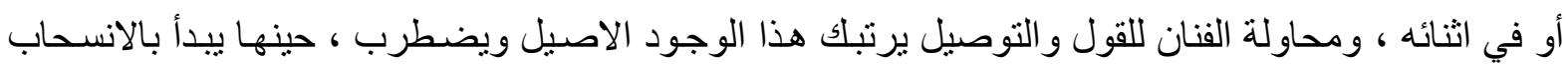

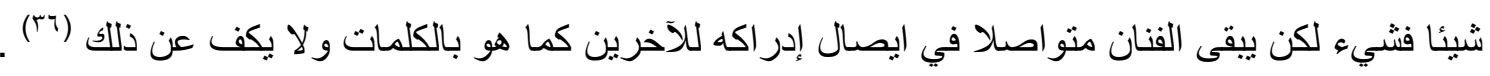
لقد لاحظ لوكاتش في كتابه الخصوصية كمقولة جمالية Vo أم، إن كل تصوير جمالي للواقع فهو مليء بالانفعالات، لا كمـا هو موجود في الحياة اليومية حيث توجد هنالك اغر اض تكون بمعزل عن الوعي الذي لوني تر افق إدر اكه الحسي الذاتي انفعالات ، بحيث ان الانفعالية ستصبح عنصر مؤلف وضـروري في التكوين الفني للغرض الذي نعدّه في خاصيته فيرى لوكاتش أن كل قصيدة حب مثنل قد أُلفت من أجل أو ضد امر أة مـا أو رجل ما، وايضا لكل لوحة طبيعية طابع ما يؤمن لها وحدتها الاساسية ويعطي تعبير غالبا ما يكون معقد في الواقع سواء كان عن موقف ايجابي أو سلبي بالنسبة الى الواقع وبعض الاتجاهـات التي تعدل فيهـ. فيرى أن

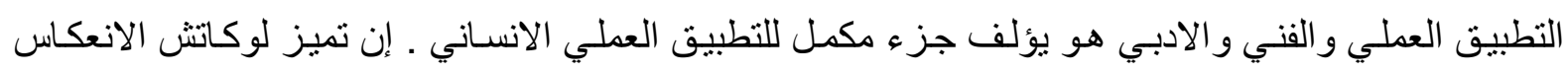

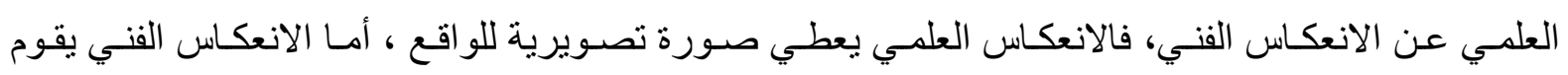

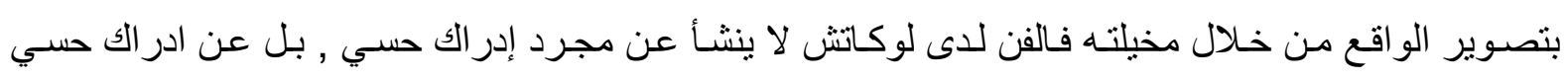
صورنه المخيلة عن عرض ثاني واذا وضع العلم الانسان أمام الواقع ذاته فالفن بقدم الانعكاس التقليدي الايمـائي للواقع، فإن التميز بين نوعي الانعكاس العلمي والفني يدخل في نظرية الوعي ، الانعكاس اللينينية مفهوم الذاتية

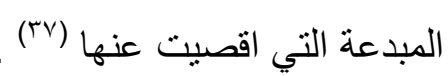
إن لوكاتش من خلال در استه لمفهوم الكلية والنمط ، حيث أعاد مفهوم النمط الذي ادخله مـاركس و انجلز وطوره عن طربق استتباطه من مقولة الكلية عند هيجل حتى يمكنه هذا المفهوم من التميز بين الإتجاه التجريدي و الطبيعي ( naturaliste)، عن الإتجاه الو اقعي الذي يعكس الواقع بشكل محسوس بـالمعنى الهيجلي، إذن مـا هـو الفرق بين الانعكاس التجريدي الطبيعي (abstrait naturaliste)، و الانعكـاس الـواقعي؟ يشـرح ذلك لوكاتش في إن الاعمـال الفنيـة للاتجـاه الطبيعي هي لا تتضـمن فقط اعمـال زولا انمـا تحتوي على التيـارات

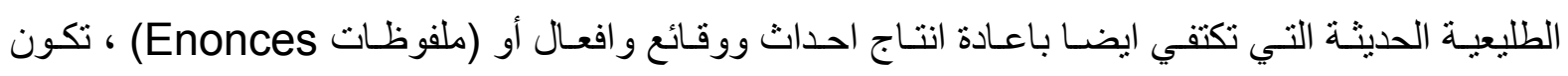
منعزلة دون إدراجها داخل كل شامل منسق ، إذن هو عبارة عن الانعكاس الجمـالي الذي لا يتجاوز الظـاهرة، بالاضافة الى أنه لا يتغلغل الىى أعماق الجوهر، أما الكاتب الو اقعي الذي ير اه لوكاتش فهو يبني مواقف و وافعنال

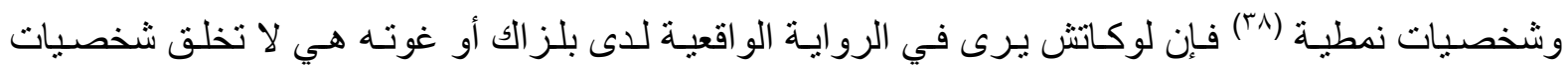
ومواقف فقط، وأحداث نمطيـة ، بـل انمـا يرجع الى التصـوير المتناسب مـع الواقع الى التجانس السببي لبنيتها السردية، ويعدّ لوكاتش من العبث البحث عن بنية كهذه في الاعمال الفنية الطبيعية والتجريبية لزو لا، وكافكا، أو بيكيت، ويسعى جاهدا في إظهار الاتساق السردي الضعيف لتلك الروايات حيث يؤكد لوكاتش في أن الو اقع في النص الذي يمثله الإتجاه الطبيعي لا يمكن فهمه بشكل جوهري ويضل لدى كاتب مثل زو لا غير قابل للادر اك

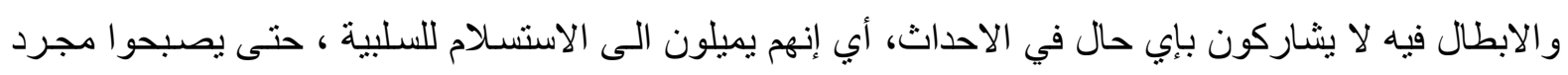

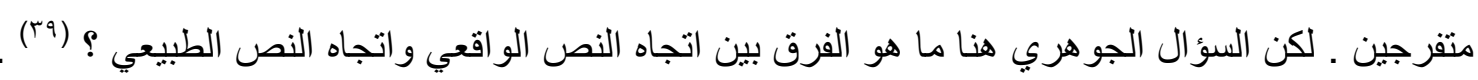


للإجابة على هذا السؤ ال حسب لوكاتش أن هنالك كتاب و اقعين امثال تولستوي أو بلز الك، ير اهم يفضلون

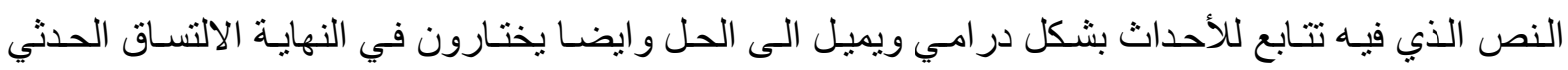
السببي، فيلحظ لوكاتش أن العمل الفني للاو هام الضائعة قد اوضح بلزالك أن المسرح هو معهد مأجور في ظل الر أسمالية ، حيث ان الدراما للابطال الأساسيين هي في الوقت نفسه در اما للمؤسسة في الاطـار الذي يتحركون فيه دراما الاشياء التي تلعب دوراً اساسياً في حياتهم، اب دراما مسرح صر اعاتهم، والحل لدى بلزاك هو جوهر الواقع الاجتماعي والتاريخي الذي وصفه. حيث تلخص الثخصيات و الاحداث و المواقف التي تتصل بها بشكل

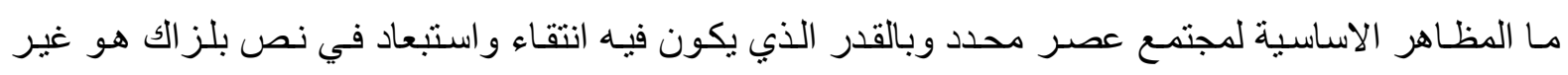

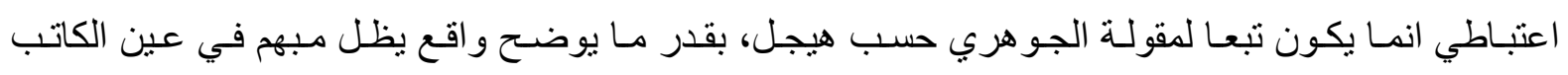
الامبريقي، اما زولا الكاتب الطبيعي فهو على العكس من بلز الك وتولستوي من ادماج وصفه الدقيق بالحدث الدر امي للرواية ، و هنا يستتج لوكاتش، وقد تبنى منظور ناريخي في أن الوصف بلعب دوراً متز ايد الاهمية في لائي الأدب الروائي بدأ من القرن الثامن عشر، الى أن يميل في القرن التاسع عشر الى أن يصبح مستقلا في مواجهة الحدث، حيث ينتهي الوصف لدى فلوبير وزولا بالتحول الى هدف في ذاته ويصبح مستقلا عن السرد (•؛).

\section{خامسا : الآيديولوجيا والواقع الابمتماعي في النص}

إن لوكاتش يركز على ضرورة البحث عن تلك العلاقة بين الثكل الفني الذي يطرحه العمل الادبي ،

وبين البنية العامة للمجتمع، وبذلك لا يولي أي عنصر من عناصر البحث أهمية على حسـاب بـاقي العناصر ،

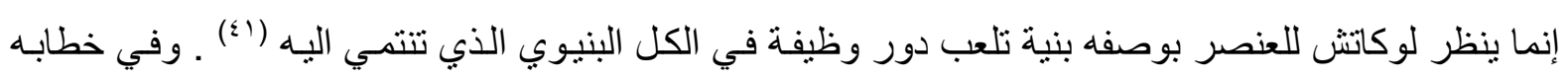

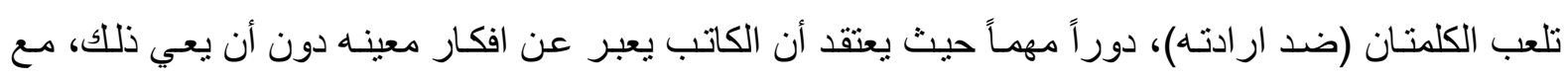

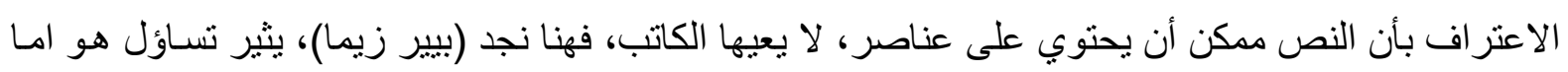

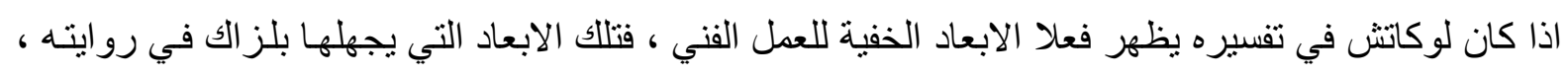
أو اذا كانت تدرج كمجرد جزء من النص البزاكي في الخطاب الماركسي عن التاريخ، حيث يثير (زيما) ، تساؤل هو كيف نجح بلز الك في تجـاوز ايديولوجيته المواليـة للسلطة ، حيث يرى زيمـا للاجابـة على التسـاؤل الاول يكون صعب، لان مفهوم اللاو عي يستخدم كثير الفرض تفسيرات اعتباطية، ويجيب زيمـا عن التسـاؤل الثاني إنه كما قال لوكاتش فإن بلزاك يتجاوز النطاق الضيق لمشرو عهد الموالي للسلطة بوصفه حسب لوكاتش

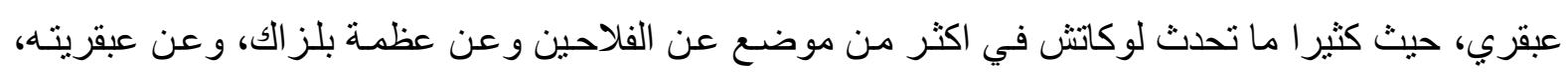

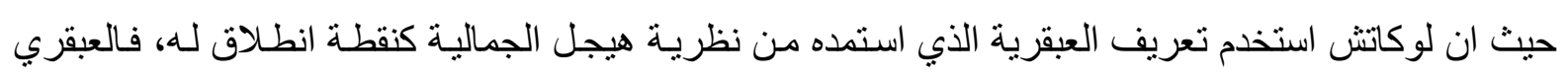
لاى لوكاتش هو وحدة الذي يتمكن من تجاوز الايديولوجيا نحو تصور و اقعي حقيقي. فيقول لوكاتش: ((إن

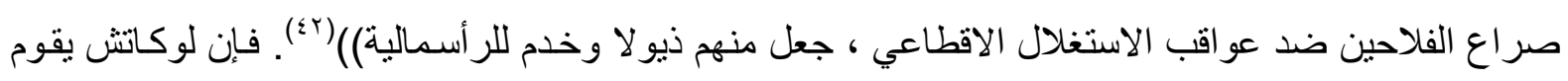

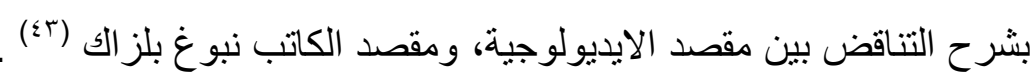

يرى لوكاتش أن الكاتب عندما يستخدم اللغـة للتعبير عن افكاره وايضـا توظيف خبرتهـ في الحياة لعمله الفني، فهو يقوم بخلق حالـة من التو افق و الانسـام والتفاعل بين اللغـة والافكار لديـه وتجاربـه الخاصـة، حيث 
غالبا ما بستخدم في خطابه لغة عادية ومألوفة والسبب في ذلك لانه يقوم بنقل وجهات نظر مختلفة ووضعيات حياتية معينة ولشخصيات متناقضة، في الفكر و الحياة، فمن هنا ستكون مستويات اللغة تعبير عن هذه التناقضـات

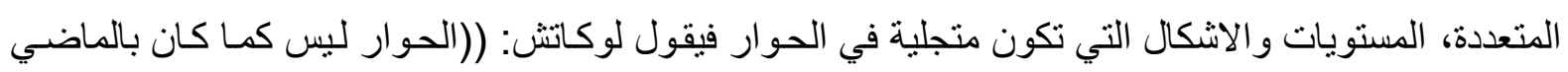
تعبيرا عن الكفاح أو الصر اع بين الناس وعن تصادمهم بل هو مرور انسيابي، مرور عابر للناس بعضهم جنب بعض، اذ لم يعد يعدد الى تطويع اللغة اليومية للارتقاء بالجو هري في مطامح الانسان الى ذروة عاطفية وفكريـة

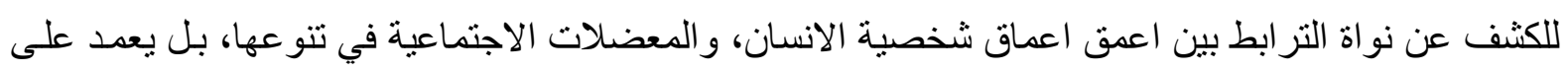

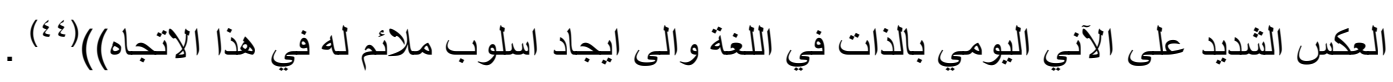
لقد شبه لوكاتش النص الادبي من حيث بنيته بآلية / العالم . حيث لا يكون في هذه الحالة مجرد قول عن كن

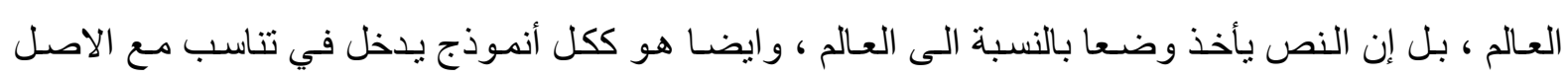

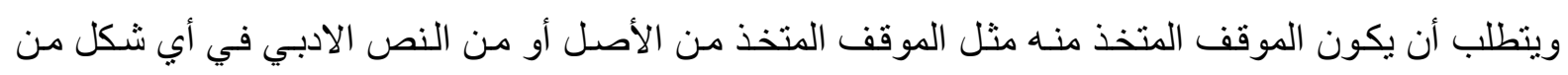
اثكاله لان تغير العالم وتغيير الوجود الاجتماعي، واشكال هذا الوجود تعطي الانعكاس الأنموذجي لدى لوكاتش

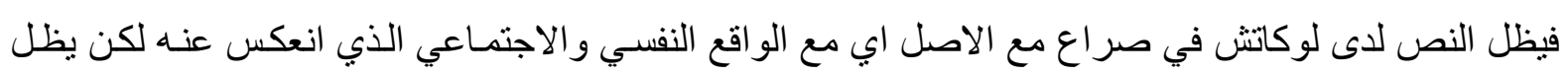
عند لوكاتش النص لله خصوصيته وللكاتب وضع منميز في لغته وتكوينه وفي رؤيته للعالم والذات(ه؛).

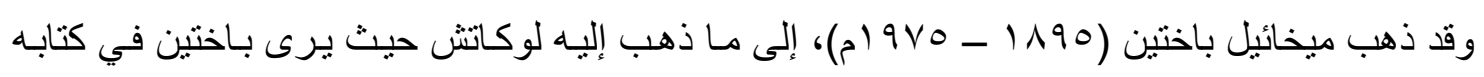
الماركسية وفلسفة اللغـة فيقول: ((تتكثف كل كلمـة، كما نعلم، حلبة مصنغرة وتتقاطع فيها لتتصسار ع لهجـات

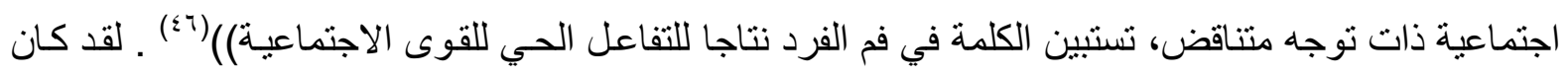
باختين متكئً على وضع الكلمة الاجتماعي التي لا يكون لها وجود إلا من خلال علاقاتها بالكلمـات الإجتماعية الأخرى، وكذلك تحدث باختين الى حد الاسهاب تقريبا عن حياة الكلمة كأنه يقول في تللك الكلمة في الروايـة إنها تعيش خارج ذاتها في توجهها الحي الى الموضوع ، فلو أغفلنا هذا التوجه حتى النهاية سوف لن تنقى بين أيدينا إلا جثة الكلمة العارية و التي لا نستطيع أن نعرف فيها شيء و ولا عن وضع الكلمة الاجتماعي و ايضا عن مصير

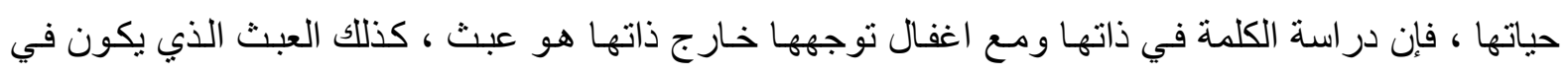
در اسة المعاناة النفسية خارج الو اقع الفعلي المتوجه اليه هذه المعاناة و المحكومـة بـه ، حيث تعيش الكلمـة خـارج ذاتها أب في حياة يومية تؤكدها مادة متميزة تؤمن حوار البشر وتعارفهم، غير انها وهي تتيح للآخرين وتتكلم

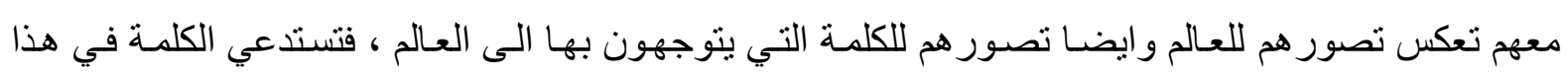
التعيين الايديولوجيا وتقد ذاتها كحامل ايديولوجي، و هذا مـا يقتضي لتصبح حلبة مصسرة تتقاطع فيها اللهجات

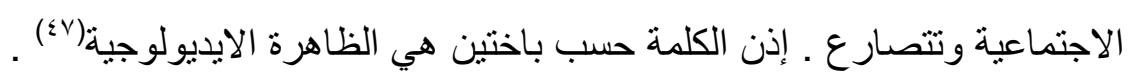
فالكلمة على ما هي عليه فإنها تحيل الى المجتمع و التاريخ بل وتصبح ايضا تحو لاتها ككلمـة اثنارة والى في تحو لات في المجتمع و التاريخ سويةً ، فالكلمة محملة دائمـا بمضمون أو معنى ايديولوجي أو حدثي فـإن الكلمـة الطاهرة والمكثفة، بطهرهـا الذاتي هي لا وجود لها وذلك لانها في الاستعمال اليومي لا تتفصل عن المفهوم الايديولوجي فهو محايث لها، وانها لا تحقق استعمالها إلا بفضل الايديولوجيا التي لازمتها ، لذلك فإن الفصل 
بين الكلمة وما تحمله من ايديولوجيا سيلغي دلالة الكلمة فتصبح مجرد إثـارة بعد أن كانت إثـارة لغويـة أي أنـه

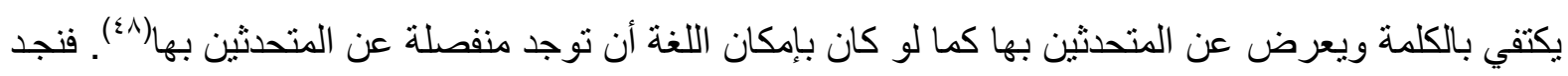
باختين يربط الدلالات و اللغة مع المجتمع , من دون إن يغفل دور المبدع الذي لجأ إلى مثل هذا النوع دون غيره

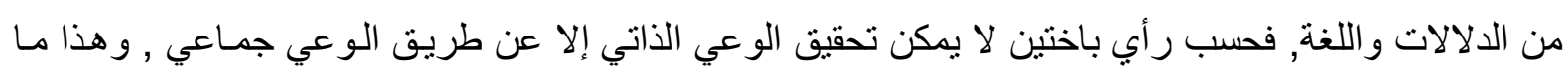

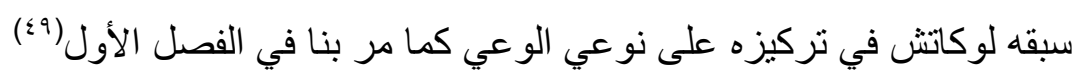

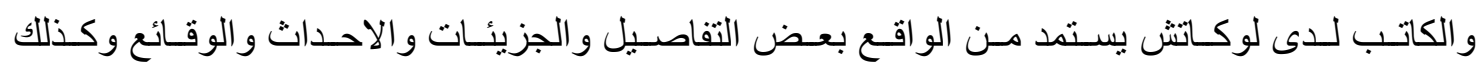
الثخصيات, لييني عالم خاص به, وذللك وفق ما هو محتمل وقوعـه من خلال أجر اءه بعض التغييرات, وعن

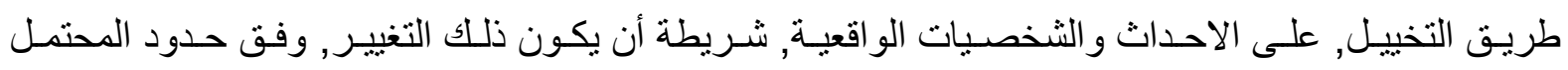
و الممكن, ويشر ح لوكاتش كيف يحقق الكاتب ذللك عن طريق, اختباره الاساسـي في بنيـة الواقع وتركيباته, و أيضا ما ير اها مناسبة للتعبير عن أفكاره ومواقفه ثم يقوم بأعادة تركيبها وصياغتها وتنسيقها, ضمن ترتيب تحددها رؤيته وثقافته و إدر اكه لسيرورة الحياة , ويوضـح لوكاتش كيف تمـر عملية الخلق الفني بمـرحلتين,

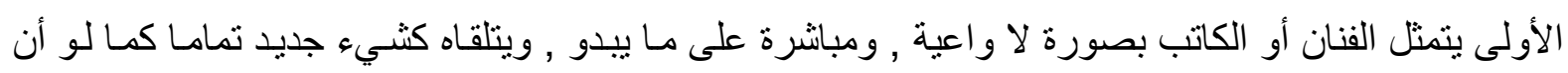

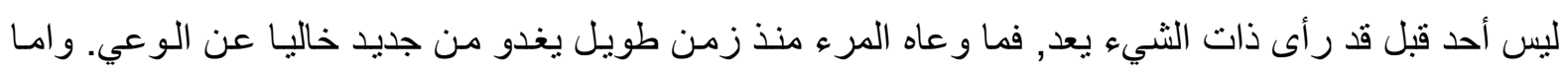

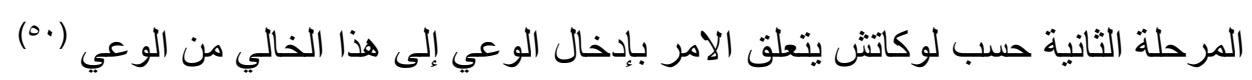
و هناك مسألة أخرى هي مسألة الكونية التي يشير لها لوكاتش إلى أن الكاتب الذي يمارس تأثير عالمي في أعماله الفنية فهو يظفر بأثر قوي مزدوج ، فمن الناحية الاولى يقوم بإصـال ثقافة وطنه بالعـالم الخـارجي

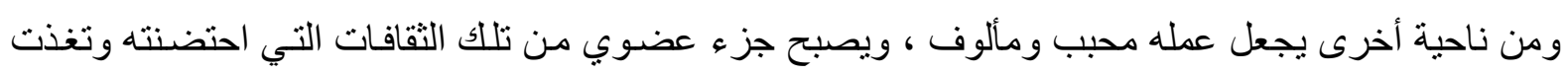
منه ، فيرى لوكاتش أنه يجب مر اعاة الضرورة الأدبية للوطن المنقولة اليه تلك الأعمـال، فالأدب العظيم مهمـا كانت قدرته في امتصاص العناصر الغريبة عنه فله تطور خاص به وهذا التطور الخاص يكون محكوم بطبيعة

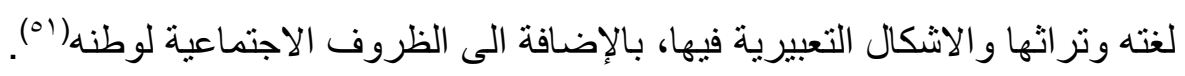
ويطرح لوكاتش مثالا عن الكاتب الاتجليزي (برنارد شو)، الذي اعترض على من حاولوا تفسير أعماله على ضوء من تأثير ات (أبسن) و(نيتشه)، عليه وبرر ذلك وجود كثير من الكتاب الانجليز والذين اعمالهم تمتلئ بكثير من افكار وعناصر دعت ناقديها الى البحث عن مصادر اجنبية ، ولوكاتش لا يأخذ بهذا المبرر فيرى اذا كان (برنارد شو) يشير لبعض الكتاب الانجليز كمصادر أقرب اليه كـ (صموئيل بتلر)، فهل هو مجهول تقريبا

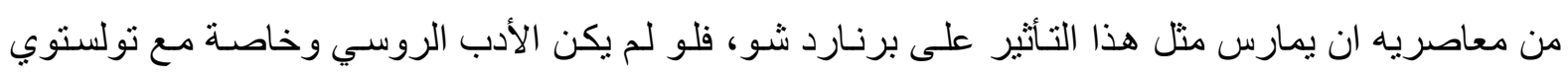

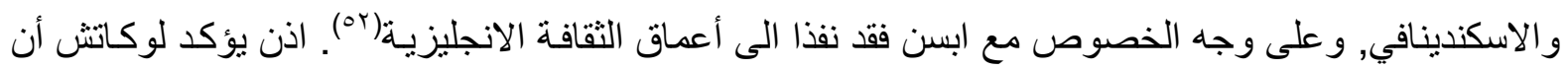
تأثثر الأدب الاجنبي لا يكون عميقا وذا أثر عظيم اذا لم تعمل في أرض الوطن أو على أقل تقدير في طبقاتها

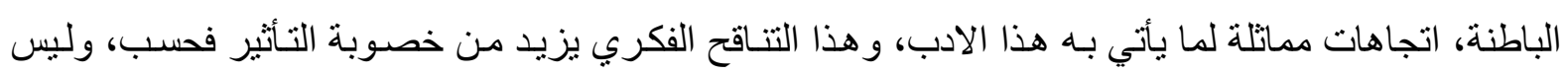

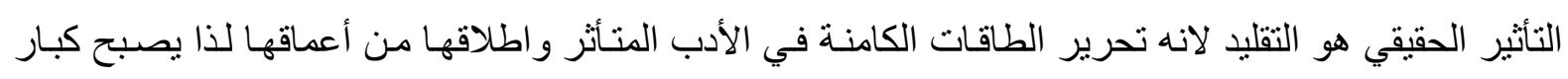
الكتاب العالميين هم عنصر ايجابي يسهم عن غير قصد في تكوين الآداب القوميـة الاجنبيـة فإنهم يسـاعدون في 
انبثاق وتتوير طاقاتها بعكس الكتاب الذين لا يظفرون إلا بنجاح موقوت عارض لانهم لا يكادون أن يمسوا سوا

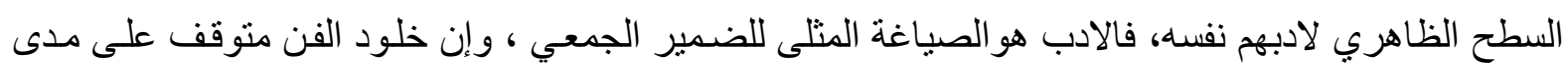

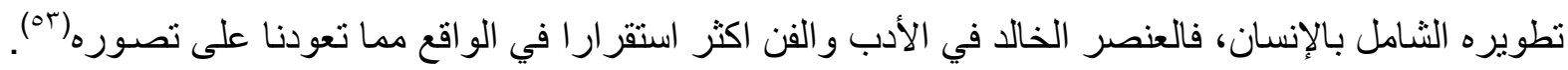
وكان مقياس ذلك في العصور القديمة هو وجود كتابـات تحرص الاجيـال المتعاقبة على الاحتفاظ بمخطوطاتها مع أنه وجود كتابات ومخطوطات أخرى لا تحضى بالعنايـة نفسها. فإن عامل الفاعليـة المباشرة التي يمارسـها

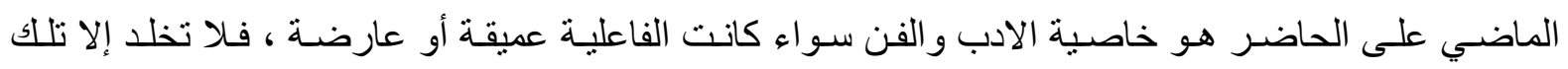

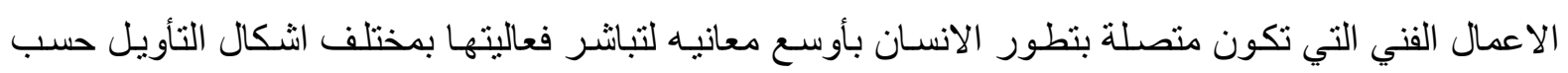

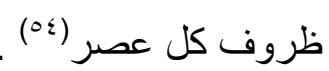

أذن حسب لوكـاتش أن العلاقـة الجدليـة بين الفكر والواقع , التـي أساسـها هيجل ومـاركس , ووضـعية خطابهما الجدلي وحدود فهم لوكاتش لمسألة اللغة عندهما , فعدّ لوكاتش أن اللغـة لها دور فعال ومهم في تغيير الحياة الاجتماعية, وأيضـاً بعث الوعي الاجتمـاعي عند الأفراد. لان لغـة الوعي الفلسفي تؤسس لفاعلية وحدة

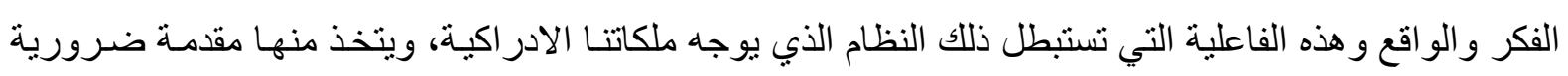
لممارسة الوعي بوصفه موضو عا للطبيعة، لذلك فالتفكير يساعد الذات على الفهم بحكم أن مقو لات الفكر تختزل

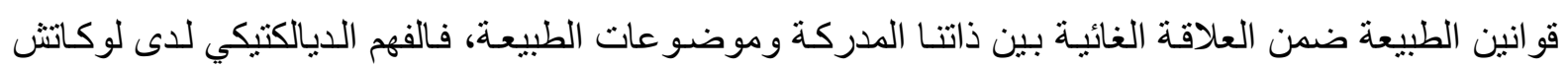

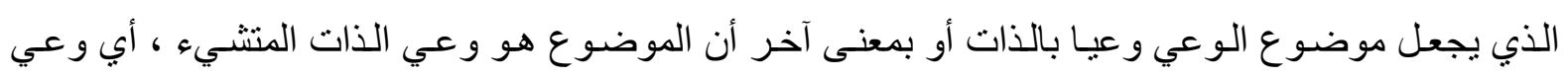
الذات كموضوع (00)

الغخاتمهة:

إن لوكاتش قد استند على المادية الجدلية ورفض عزل النص و اغلاقه على نفسه، فهو يركز على النظام التركيبي اللغوي في النص الادبي، وإن كل تصـوير جمالي للواقع عنده مليء بالانفعالات كمـا هو موجود في الحياة اليومية، فالانفعاليـة عنصر ضروري في تكوين العمل الفني والفنان الكاتب عنده عامل مـادي قائم في مكان وسيط يخلق حالة من الانسجام و التفاعل بين اللغـة والافكـار لديه وتجاربـه الخاصـة, وخلص البحث إلى ولى النتائج الآثية . مانية

ا - لابد على المر ء رصد كل التناقضات الاجتماعية وكثف خباياها، في الاعمال الفنية وخصوصا عندما تكون

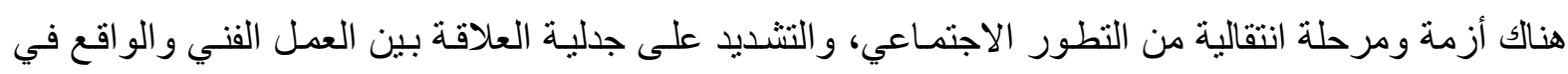
عكس الايديولوجية السائدة، والتفريق بين اليديولوجيا المؤلف كإنسـان و ايديولوجية تأليفه التي لا تكون خاضعة ولنه

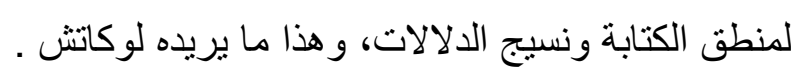

זـ لقد حاول لوكاتش من خلال اهتمامه بالروايـة كجنس أدبي ، بوصفها تمثل الوجـه الكاثف للتطور الحقيقي

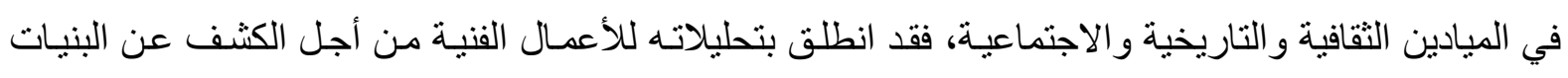
الدلالية في نصـوص الاعمـال الفنيـة ، سـاعيا منـه ور اء رؤيسة شمولية ، يسعى الفرد بلو غهـا من خـلال تفاعلـه 
الايجابي مع حركة دائبة لسير التأريخ ، و لان الرواية فضـاؤها مفتوح للثخصيات ، فتظهر فيها الحقيقة بشكل

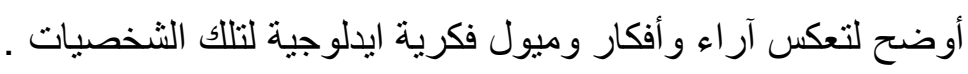

\section{هوامش البمث:}

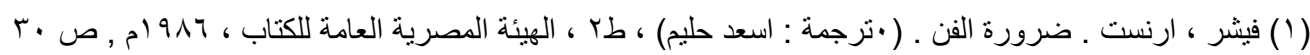

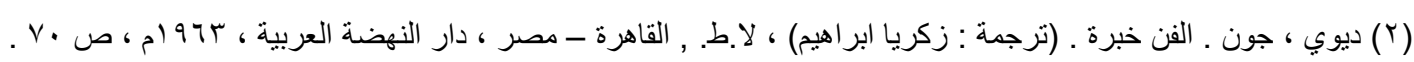

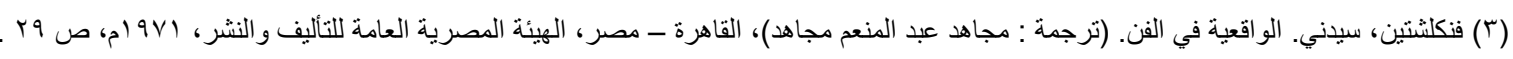

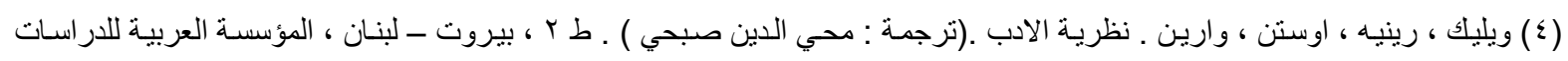

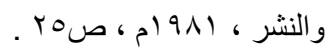

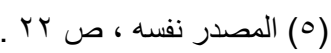

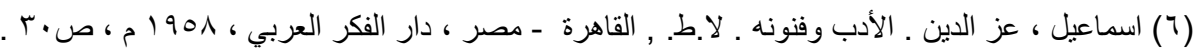

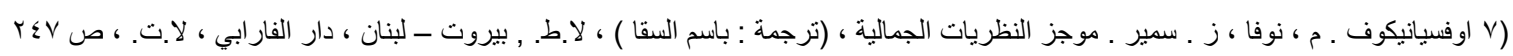

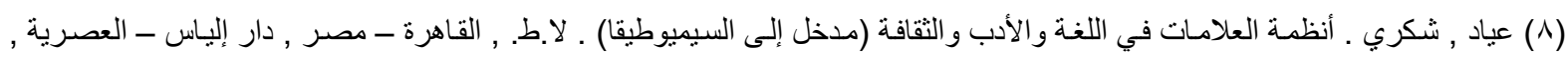

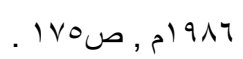

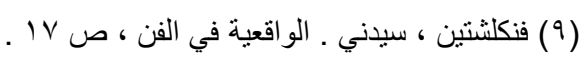

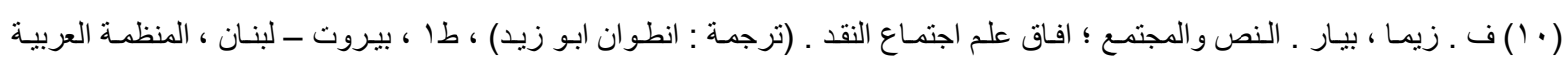

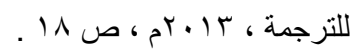

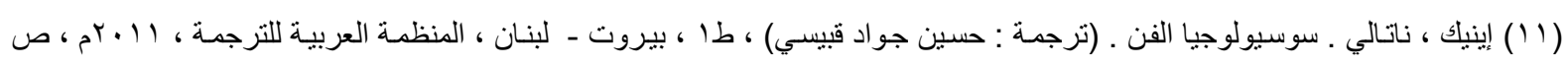
. $\varepsilon r-\varepsilon r$

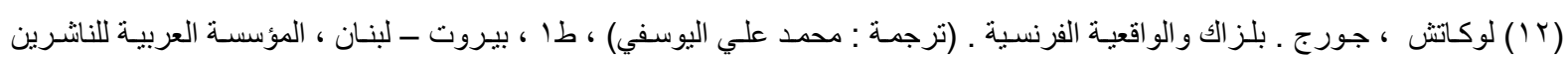

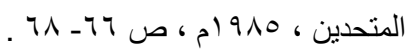

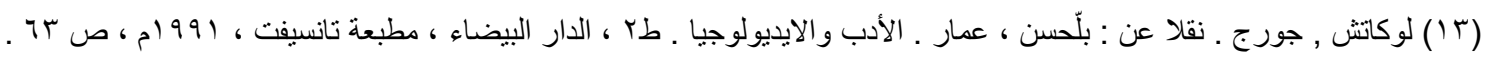

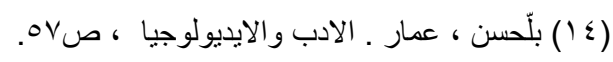

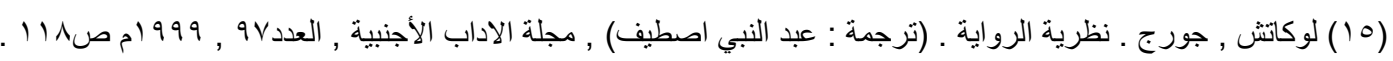
(17) Lukacs, Gyorjy .Soul and Form . (Y.1.) USA, (Translated : John T.Sanders and Katie Terezakis), Columbia University Press,p. i Ar.

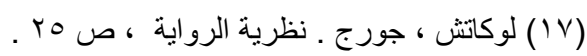

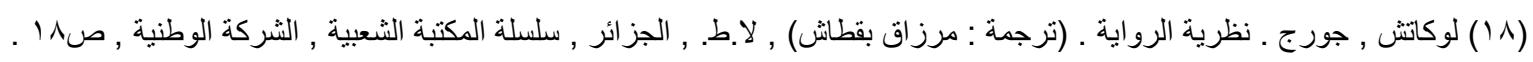

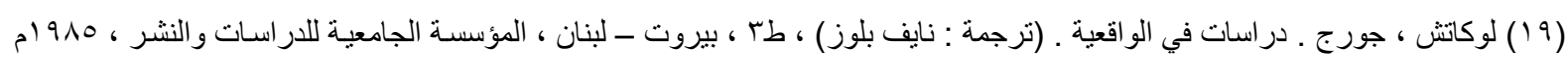

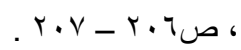

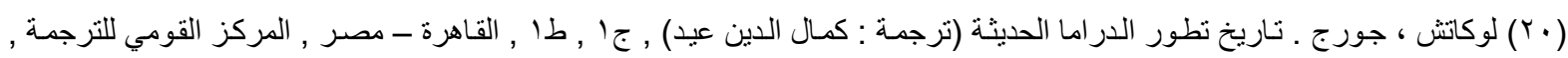
ror-rol, , r. Th

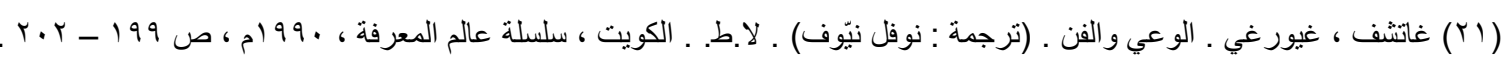

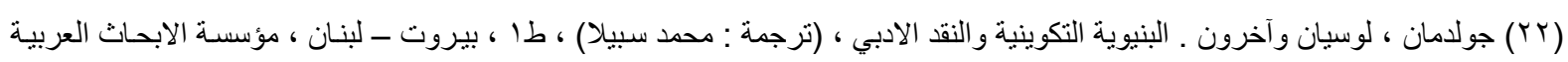

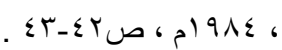

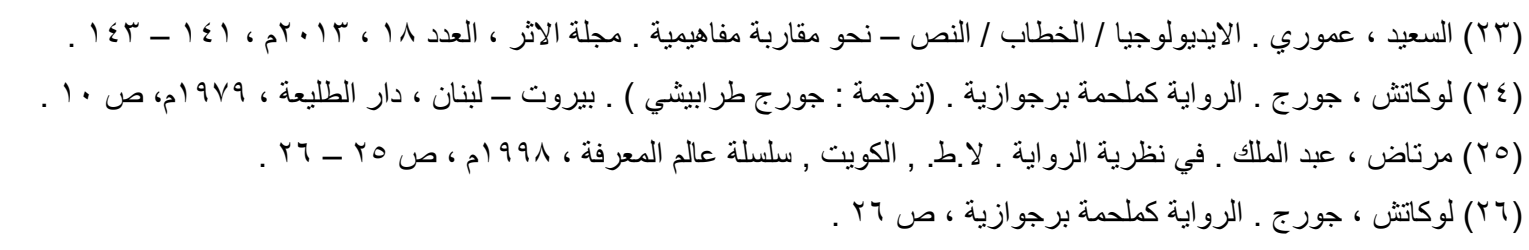

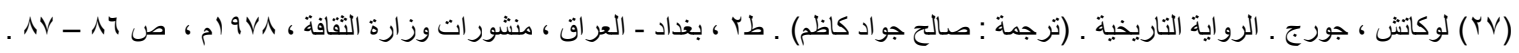

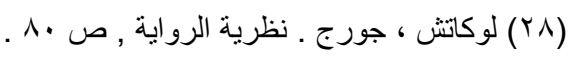




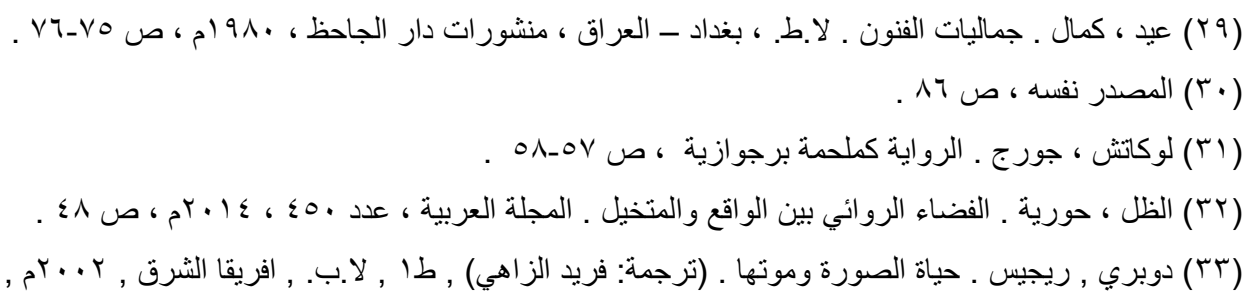
( $(\varepsilon)$ Thompson, Michael j. .Ontology and Totality : Reconstructing Lukacs Concept of Critical Theory (Georg Lukacs Reconsidered), (r. II) London, Continwm International Publishing Group, p. rrr - r ro .

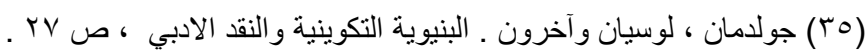

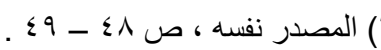

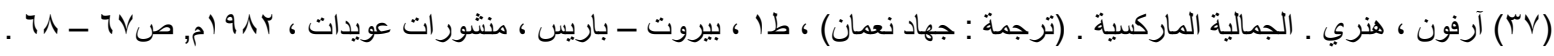

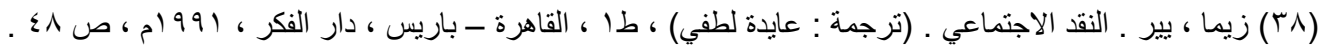

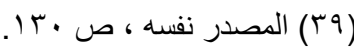

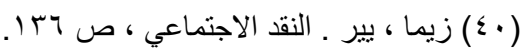

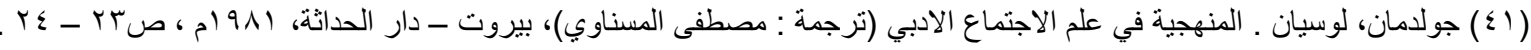

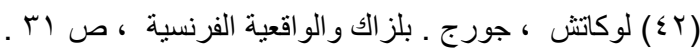

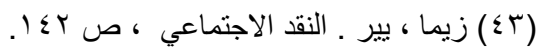

(

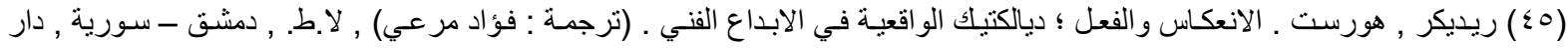

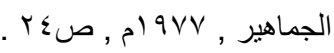

(ך؟) باختين ، ميخائيل ـ الماركسية وفلسفة اللغة ـ (ترجمة : محمد البكري و يمنى العيد) ، لا.ط. , الدار البيضـاء ـ المغرب ، دار توبقال ،

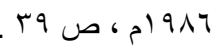

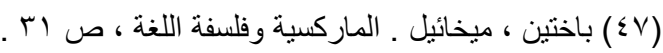

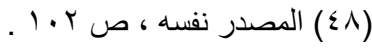

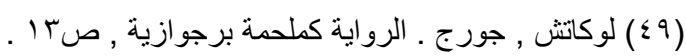

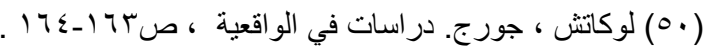

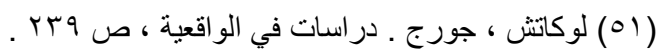

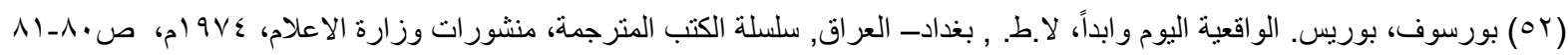

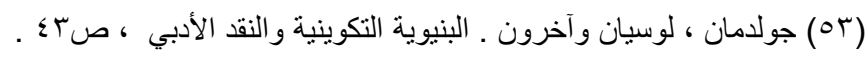
(

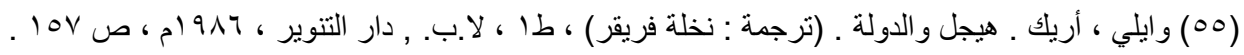

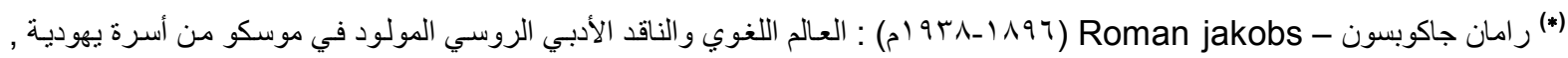

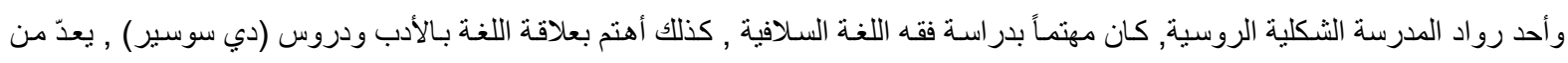

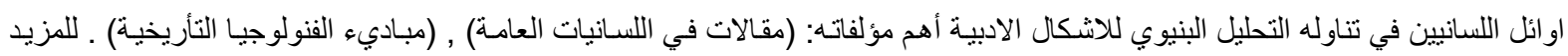

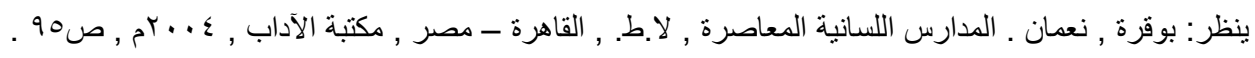

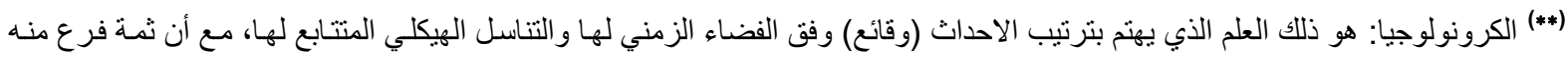

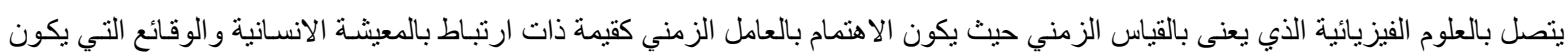
ناثير ها بالو اقع اليومي حياة البشر بمعنى الالسنة والتاربخ، فالمضي في فهم وتفسبر التأريخ والتجارب الانسـانية في انها تقوم في مسار خطي،

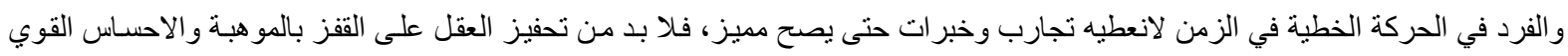

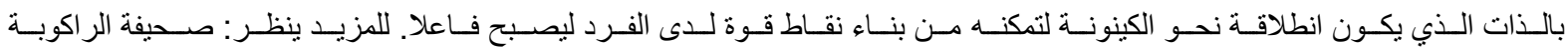


